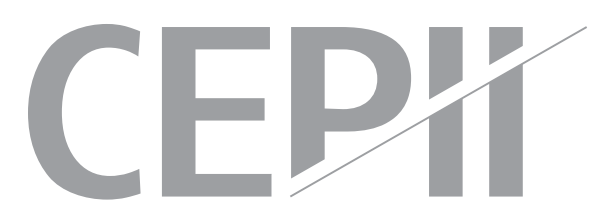

\title{
A European Disease? Non-tradable Inflation and Real Interest Rate Divergence
}

\author{
Sophie Piton
}

\section{Highlights}

- This paper studies the contribution of real interest rate divergence to the dynamics of the relative price of non-tradables within Europe.

- It suggests an extension of the traditional Balassa-Samuelson framework to analyze the impact of the real interest rate on the dynamics of the relative price.

I It documents the expansion of the non-tradable sector in the periphery before the euro crisis.

- It carries out an econometric estimation for 11 EA countries over 1995-2013 and quantifies the contribution of the pure Balassa-Samuelson effect and the impact of the interest rate on non-tradable relative prices.

- In Greece, the fall in the real interest rate over 1995-2008 could explain almost half of the non-tradable price increase relative to the EA average, while in Germany the increase in the real interest rate might have contributed up to $7 \%$ of the decrease of the non-tradable price relative to the average of the EA. 


\section{Abstract}

This paper studies the contribution of real interest rate divergence to the dynamics of the relative price of nontradables within Europe. Based on a model by De Gregorio et al. (1994), it shows that the real interest rate fall in the Euro Area (EA) periphery following the single currency's inception induced an increase in the relative price of nontradable goods. Using a new dataset, it documents the dynamics of the tradable and the non-tradable sectors over 1995-2013 and the expansion of the non-tradable sector in the periphery before the euro crisis. It then carries out an econometric estimation for 11 EA countries over 1995-2013 and quantifies the contribution of the pure BalassaSamuelson effect and the impact of the interest rate on non-tradable relative prices. Diverging evolution in the interest rate impacted greatly the evolution of non-tradable relative prices within the euro area over the period. In Greece, the fall in the real interest rate over 1995-2008 could explain almost half of the non-tradable price increase relative to the EA average, while in Germany the increase in the real interest rate might have contributed up to $7 \%$ of the decrease of the non-tradable price relative to the average of the EA.

\section{Keywords}

Non-tradable Prices, Balassa-Samuelson Effect, Real Interest Rate.

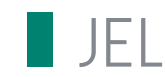

F41, F45, E43.

\section{Working Paper}

\section{CEPI}

CEPII (Centre d'Etudes Prospectives et d'Informations Internationales) is a French institute dedicated to producing independent, policyoriented economic research helpful to understand the international economic environment and challenges in the areas of trade policy, competitiveness, macroeconomics, international finance and growth.
CEPII Working Paper

Contributing to research in international economics

C C CEPII, PARIS, 2016

All rights reserved. Opinions expressed in this publication are those of the author(s) alone.

$\begin{array}{ll}\text { Editorial Director: } & \text { CEPII } \\ \text { Sébastien Jean } & \begin{array}{l}113, \text { rue de Grenelle } \\ 75007 \text { Paris }\end{array} \\ \text { Production: } & +33153685500 \\ \text { Laure Boivin } & \text { www.cepii.fr } \\ \text { No ISSN: } 1293-2574 & \text { Press contact: presse@ }\end{array}$




\section{A European Disease? Non-tradable inflation and real interest rate divergence}

Sophie Piton*

This version: October 20, 2016

\section{Contents}

1 Introduction

2 Conceptual framework

3 Data 6

3.1 Data sources . . . . . . . . . . . . . . . . . . . . . . 6

3.2 Defining tradability . . . . . . . . . . . . . . . . . . 6

3.3 Stylized facts: the drift from the tradable to the non-tradable sector . . . . . . . . 8

4 Determinants of the relative price of non-tradables

4.1 Panel unit root and cointegration tests . . . . . . . . . . . . . . 13

4.2 Estimation of the long-run relationship . . . . . . . . . . . . . . . . . . . . 14

4.3 Robustness tests . . . . . . . . . . . . . . . . . . . . . . . . . . 16

5 Concluding Remarks $\quad 20$

$\begin{array}{ll}\text { Appendix } & 23\end{array}$

${ }^{*}$ CEPII \& Paris School of Economics - University Paris 1 Panthéon-Sorbonne. Contact: sophie.piton@cepii.fr. I am indebted to Valérie Mignon, Dramane Coulibaly, Laurence Nayman and participants to the 2015 Cesifo-Delphi Conference on Current Account Adjustments for helpful comments and advice. I am especially thankful for Agnès Bénassy-Quéré's extensive advice and support. 


\section{Introduction}

When the euro was introduced, conditions for economic convergence -the process of narrowing income gaps between lower and higher income countries- seemed to be present. ${ }^{1}$ Nominal interest rates between higher and lower income countries had converged rapidly ${ }^{2}$ and capital was flowing from the richer (the "core") to the poorer (the "periphery") countries of the area. This convergence process was supposed to be the main reason behind the strong macroeconomic divergence between the core and the periphery, and the imbalances were supposed to be reduced as countries would converge. The 2010 euro crisis has challenged this view, with macroeconomic divergence among countries pointed to as reflecting bad imbalances. In particular, debates have emerged to reassess the mechanisms behind the divergence in inflation rates across countries and behind substantial price differentials between tradable and non-tradable goods in some countries. Even though there is evidence of a convergence of tradable prices across Europe and higher productivity growth in the tradable sectors of catching-up economies, there seems to be a growing consensus that the Balassa-Samuelson (BS) effect ${ }^{3}$ cannot be the sole explanation to the steep rise in the non-tradable relative to the tradable price in the Euro Area (EA) periphery before the crisis (Estrada et al., 2013).

This paper further investigates the mechanisms behind the divergence of relative (non-tradable to tradable) prices across Europe. The starting point is Figure 1 which shows the evolution of relative prices and real interest rates in the periphery compared to core countries over 1995-2013. The periphery, facing a steep increase in relative prices, also faced a strong decrease in real interest rates up to 2008. Introducing two factors of production in the BS framework, the paper shows that the real interest rate fall in the EA periphery following the single currency's inception induced an increase in the relative price of non-tradable goods. Using a new dataset, it then documents the dynamics of the tradable relative to the non-tradable sector over 1995-2013 and highlights the expansion of the non-tradable sector in the periphery before the euro crisis. Finally, it carries out an econometric estimation for 11 EA countries over 1995-2013 to quantify the contribution of the pure BS effect and that of the interest rate reduction on non-tradable relative prices.

A growing literature has analyzed the impact of falling interest rates on the increase in relative prices of non-tradables. In 1983 already, Dornbusch (1983) showed how an exogenous disturbance in the real interest rate can affect the price of non-traded goods by fueling a demand boom. This argument has also been suggested more recently by Fagan and Gaspar (2007). Other papers analyze the impact of the interest rate on the supply side rather than on the demand-side of the economy: Reis (2013), studying the case of Portugal, suggests that capital inflows were misallocated within the non-tradable sector due to financial frictions, fueling transitory price increases in this sector. Other authors look at the impact of such misallocation on the sustainability of the current account and the probability of a balance of payment crisis (Giavazzi and Spaventa, 2011; Kalantzis, 2015).

This paper departs from these analyses in the way that it studies the impact of interest rate variations in a BS framework. The BS framework has already been subject to various extensions

\footnotetext{
${ }^{1}$ Blanchard and Giavazzi (2002) suggested that current account deficits in the periphery after the euro's inception reflected mainly a catch-up and convergence process.

${ }^{2}$ The periphery faced, on average between $2001-2008$, a real rate of $0.26 \%$ against $1.4 \%$ for the rest of the euro area as a whole (Ameco, February 2016.)

${ }^{3}$ Balassa (1964) and Samuelson (1964) suggested that higher inflation rates in catching-up economies could reflect a process of real convergence: assuming the law of one price holds for tradable goods, productivity growth in this sector pushes real wages up both in the tradable sector and the non-tradable one; it results in an increase in the relative price of non-tradable goods and thus in a real exchange rate appreciation in catching-up economies.
} 
Figure 1 - Relative prices and real interest rates in the periphery vs. core countries, 1995-2013 indices $1995=100$

Relative (non-tradable to tradable) prices

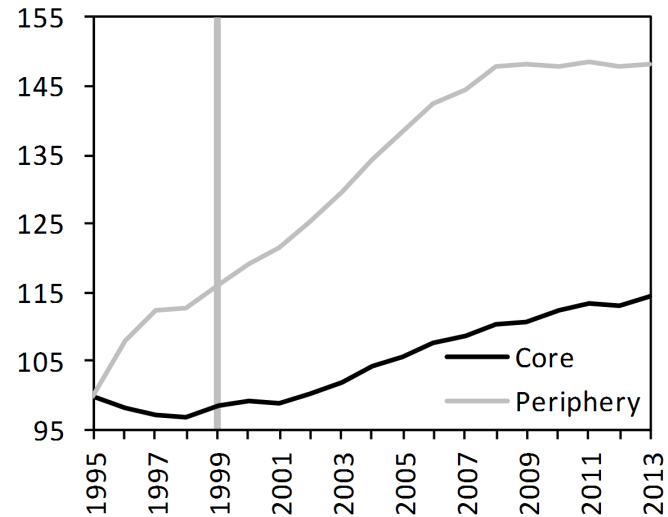

Real interest rates

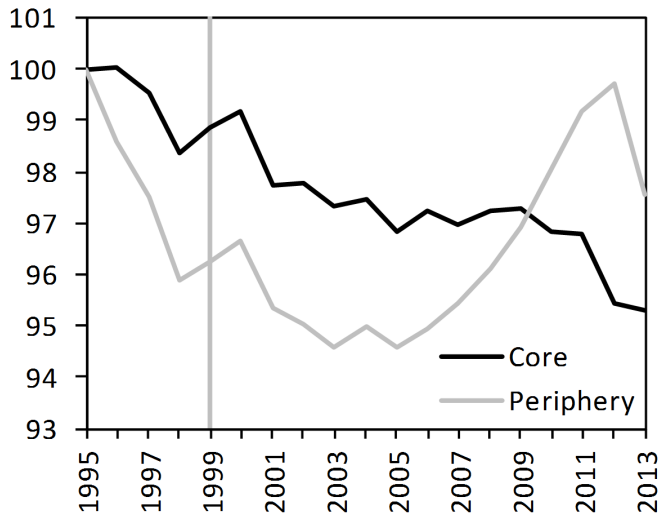

Source: author's calculations using Eurostat, $\mathrm{BACl}$ and UN ServiceTrade and Ameco.

Note: relative prices are measured using the $10 \%$ threshold for tradability and are the ratio of nontradable prices relative to the tradable price of the EA11. Variables for each group are weighted averages (weight: gross value added at current prices). The real interest rate is deflated by GDP deflators. The periphery includes: Spain, Portugal, Italy, Ireland, Greece. Core countries are: Austria, Belgium, Germany, Finland, France, Netherlands. The grey vertical lines indicate the euro introduction (1999).

to explain the permanent drift in non-tradable prices. Among others, De Gregorio et al. (1994) suggest that it could be explained by an exogenous demand-shift towards non-tradable goods. More recently Bénassy-Quéré and Coulibaly (2014) suggest that inflation differentials in Europe also originate in heterogeneous market regulations. This paper shows that in the long term, a permanent and exogenous decrease in the interest rate will lead to a permanent drift in nontradable prices as long as the non-tradable sector is labor-intensive. This is, to our knowledge, the first attempt to analyze the impact of the interest rate in a BS framework.

The remainder of the paper is organized as follows. Section 2 extends the usual BS theoretical framework to analyze the impact of a fall in the real interest rate on the non-tradable relative price. Section 3 describes the dataset and the construction of a tradability indicator, and then documents the dynamics of the non-tradable and tradable sectors over 1995-2013 in 11 countries of the EA. Section 4 presents the econometric strategy, reports empirical estimation results and robustness tests. Section 5 concludes.

\section{Conceptual framework}

The workhorse model to analyze the evolution of non-tradable prices in an open economy is the framework set by Balassa (1964) and by Samuelson (1964). Their model features a small open economy with a perfectly competitive tradable sector (the price being determined by the world market), and a non-tradable sector (the price being determined domestically). Labor is the only factor of production. They show that, assuming the law of one price holds for tradable goods, 
productivity growth in this sector pushes real wages up both in the tradable sector and in the non-tradable one. This results in an increase in the relative price of non-tradable goods and thus in a real-exchange rate appreciation, which is commonly known as the BS effect. Several theoretical extensions have been proposed in the literature. ${ }^{4}$ Some of them consider two factors of production (labor and capital), or examine the implications of incorporating a demand-side in the BS framework (see, among others, De Gregorio et al., 1994; Obstfeld and Rogoff, 1996; BénassyQuéré and Coulibaly, 2014). ${ }^{5}$ This paper is the first attempt to look at the impact of an exogenous change in the interest rate on the evolution of the non-tradable relative price. It focuses on the supply-side and builds on the framework set by De Gregorio et al. (1994) to show the impact of both faster productivity growth in the tradable sector and an exogenous and permanent fall in the interest rate on the relative price of non-tradable goods.

The model features a small open economy with two goods: a tradable, the numeraire, whose market is perfectly competitive and subject to the law of one price; a non-tradable good, which price is set domestically. Production takes place using two inputs: capital (mobile internationally and between sectors) and labor (mobile between sectors but not internationally). Labor sectoral mobility ensures that workers earn the same wage in either sector whereas capital international mobility ensures that the interest rate is given internationally.

Representative firms in each sector face a Cobb Douglas production function with two factors of production, of the form:

$$
\begin{aligned}
& Y_{T}=A_{T} K_{T}^{\alpha_{T}} L_{T}^{1-\alpha_{T}} \\
& Y_{N}=A_{N} K_{N}^{\alpha_{N}} L_{N}^{1-\alpha_{N}}
\end{aligned}
$$

where the subscripts $T$ and $N$ denote the tradable and non-tradable goods, $Y$ denotes real output, $L$ labor inputs and $K$ capital. $\alpha_{T}, \alpha_{N}$ represent capital intensity in each sector $\left(\alpha_{T}, \alpha_{N} \in\right] 0,1[$ ). Given that the tradable good acts as a numeraire, and given that the interest rate $r$ is exogenous, combining first order conditions in the tradable sector yields the equation for the real wage (nominal wage deflated by the numeraire $T$ ), $\omega$ :

$$
\omega=r^{-\frac{\alpha_{T}}{1-\alpha_{T}}} A_{T}^{\frac{1}{1-\alpha_{T}}} \alpha_{T}^{\frac{\alpha_{T}}{1-\alpha_{T}}}\left(1-\alpha_{T}\right)
$$

Combining first order conditions in the non-tradable sector, given $r$ and $\omega$, yields the equation for the non-tradable relative price $p$ :

$$
p=\frac{1}{A_{N}}\left(\frac{\omega}{1-\alpha_{N}}\right)^{\left(1-\alpha_{N}\right)}\left(\frac{r}{\alpha_{N}}\right)^{\alpha_{N}}
$$

Plugging (3) into (4), we get that the non-tradable relative price is determined entirely by technological conditions and is independent of demand conditions. The relative price depends on the rate of interest $(r)$ and on the tradable and non-tradable sector productivities $\left(A_{T}, A_{N}\right)$ and capital intensities $\left(\alpha_{T}, \alpha_{N}\right)$ :

$$
p=r^{\frac{\alpha_{N}-\alpha_{T}}{1-\alpha_{T}}} \frac{\left[A_{T}\left(1-\alpha_{T}\right)^{1-\alpha_{T}} \alpha_{T}^{\alpha_{T}}\right]^{\frac{1-\alpha_{N}}{1-\alpha_{T}}}}{A_{N}\left(1-\alpha_{N}\right)^{1-\alpha_{N}} \alpha_{T}^{\alpha_{N}}}
$$

\footnotetext{
${ }^{4}$ See Bahmani-Oskooee and Nasir (2005) for a review.

${ }^{5}$ In all cases, demand shocks appear unable to move the real exchange rate in the long run.
} 
The BS effect postulating a positive link between faster productivity growth in the tradable sector and the relative price of the non-tradable good is straightforward. Other things constant, a rise in the productivity of the tradable sector $\left(A_{T}\right)$ decreases the price of this sector relative the nontradable one. This BS effect goes through the impact of $A_{T}$ on $\omega$ :

$$
\frac{d \omega}{d A_{T}}=\frac{1}{1-\alpha_{T}} A_{T}^{\frac{\alpha_{T}}{1-\alpha_{T}}} r^{-\frac{\alpha_{T}}{1-\alpha_{T}}} \alpha_{T}^{\frac{\alpha_{T}}{1-\alpha_{T}}}\left(1-\alpha_{T}\right)>0
$$

This wage increase ensures that the marginal cost of tradables remains constant but it increases the marginal cost, and hence the relative price, of the non-tradable good:

$$
\frac{d p}{d A_{T}}=\frac{1-\alpha_{N}}{1-\alpha_{T}} A_{T}^{\frac{\alpha_{T}-\alpha_{N}}{1-\alpha_{T}}} r^{\frac{\alpha_{N}-\alpha_{T}}{1-\alpha_{T}}} \frac{1}{A_{N}}\left(\frac{1-\alpha_{T}}{1-\alpha_{N}}\right)^{1-\alpha_{N}} \alpha_{T}^{\frac{\alpha_{T}\left(1-\alpha_{N}\right)}{1-\alpha_{T}}} \alpha_{N}^{-\alpha_{N}}>0
$$

In turn, the impact of an exogenous and permanent fall in the interest rate on the relative nontradable price depends on the capital intensity of the non-tradable relatively to the tradable sector $\left(\alpha_{N}-\alpha_{T}\right)$. Indeed, a fall in the interest rate -all other variables remaining constant- is matched by a wage increase ensuring that the marginal cost of tradables remains constant:

$$
\frac{d \omega}{d r}=-\frac{\alpha_{T}}{1-\alpha_{T}} r^{\frac{-1}{1-\alpha_{T}}} A_{T}^{\frac{1}{1-\alpha_{T}}} \alpha_{T}^{\frac{\alpha_{T}}{1-\alpha_{T}}}\left(1-\alpha_{T}\right)<0
$$

If the non-tradable sector is relatively more (less) labor intensive, this rise in wages will increase (decrease) the marginal cost, and hence the relative price, of the non-tradable good:

$$
\frac{d p}{d r}=\frac{\alpha_{N}-\alpha_{T}}{1-\alpha_{T}} r^{-\frac{1-\alpha_{N}}{1-\alpha_{T}}} \frac{A_{T}^{\frac{1-\alpha_{N}}{1-\alpha_{T}}}}{A_{N}}\left(\frac{1-\alpha_{T}}{1-\alpha_{N}}\right)^{1-\alpha_{N}} \alpha_{T}^{\frac{\alpha_{T}\left(1-\alpha_{N}\right)}{1-\alpha_{T}}} \alpha_{N}^{-\alpha_{N}}<0 \quad \text { if } \quad \alpha_{N}<\alpha_{T}
$$

Expressing all variables relative to the Euro area (EA) average, assuming the law of one price holds in the tradable sector $\left(p_{T}=p_{T}^{E A}\right)$, and assuming, as in the literature, that productivity grows faster in the tradable sector than in the non-tradable sector, the empirically testable model is given by:

$$
\left(\frac{p_{N}}{p_{N}^{E A}}\right)=f\left(\left(\frac{A_{T}}{A_{T}^{E A}}\right),\left(\frac{r}{r^{E A}}\right)\right)
$$

where $A_{T}$ stands for productivity in the tradable sector, $r$ the real interest rate, and $E A$ subscripts stand for euro area averages. For similar productivity growth in the non-tradable sector, the country should experience a relative increase in its non-tradable price if its productivity growth in the tradable sector is stronger than the average productivity growth of the $T$ sector in the euro area: we expect a positive coefficient on the first variable. Similarly, the country is expected to experience a non-tradable price increase if its real interest rate (expressed in terms of tradables) decreases more than it does, on average, in the EA, given that the non-tradable sector is more labor intensive than the tradable one. There seems to be evidence supporting this assumption that the non-tradable sector is more labor-intensive than the tradable sector. van Riet and Roma (2006) show that services sectors are less capital intensive than the manufacturing sectors in the euro area at the beginning of the 2000s. Moreover, they show that Southern European countries tend to be characterized by a smaller average firm size than the Euro area aggregate, and have a larger share of self-employment in the service sector, making this sector even more labor intensive than in the rest of the EA. This assumption is also confirmed in the dataset used here. These results will be tested empirically after describing the dataset used and documenting patterns in the non-tradable sector inflation across Europe over 1995-2013. 


\section{Data}

\subsection{Data sources}

Most studies label the manufacturing sector as tradable and consider services sectors as nontradable. However, services represent an increasing share of advanced economies' exports. To reassess the tradability of both goods and services, one needs to construct a database allowing to compare trade in goods and services, and national accounts data at a sectoral level. Eurostat provides data for national accounts for up to 64 sectors in the NACE revision 2 classification. It provides detailed information on Gross Value Added (GVA) in current and constant prices, production at current and constant prices, employment and labor compensation for European countries. For data on trade in goods, BACl, CEPII's database based on COMTRADE, provides a harmonized world trade matrix for values at the 6-digit level of the Harmonized System of 1992. Data are available from 1989 to 2013 for 253 countries and 5699 products. Finally, for trade in services, UN ServiceTrade database provides data on services exports and imports in the BPM5 classification over 2000-2013.

All databases are converted into a 21-level NACE revision 2 classification, to get an unbalanced database ${ }^{6}$ providing data on gross value added at current and constant prices, production at current and constant prices, labor compensation at current prices, employment and the value of trade in goods and services and goods export for up to 11 EA countries (EA11) ${ }^{7}$ over 1995-2013. It is then possible to measure gross value added deflators (chained linked indices, using 1995 as the reference year) and labor apparent productivity (value added in volume per hour worked) as a proxy for total factor productivity. Finally, series on annual real ${ }^{8}$ long-term interest rates come from Ameco.

\subsection{Defining tradability}

The tradability of a good or a service sector is defined as the capacity to trade its output internationally. As in De Gregorio et al. (1994) and most of the empirical literature, the extent to which a good or a service is actually traded with a foreign country is used as a proxy for its tradability. Therefore, the tradability of each sector at the euro area (EA11) level depends on its openness ratio -the ratio of total trade (imports + exports) of the EA11 to total production in the EA11. As in De Gregorio et al. (1994) we use a threshold of $10 \%$, so a sector is considered as being tradable if the average of its openness ratio over 2000-2013 is higher than 10\% (the openness ratio for the period 1995-1999 cannot be measured since data on trade in services are not available for this period).

Figure 2 reports the openness ratio by sector on average over 2000-2013 (see Table A.1 in Appendix for more details). Unsurprisingly, agriculture, the manufacturing and mining and quarrying sectors are in the tradable sector. Concerning services, four industries are considered as tradable: accommodation and food service activities; transportation and storage; information and communication, and administrative and support service activities. The tradable sector accounts for $47 \%$ of total production, $36 \%$ of GVA (both at current prices) and 39\% of employment.

\footnotetext{
${ }^{6}$ Information on disaggregated trade in services is available only for the period 2000-2013.

${ }^{7}$ The 11 EA countries are: AT: Austria; BE: Belgium; DE: Germany; EL: Greece; ES: Spain; FI: Finland; FR: France; IE: Ireland; IT: Italy; NL: Netherlands; PT: Portugal.

${ }^{8}$ Long-term interest rate deflated by GDP deflators.
} 
Figure 2 - Openness ratio and tradability by sector, EA11 Average 2000-2013, in \%

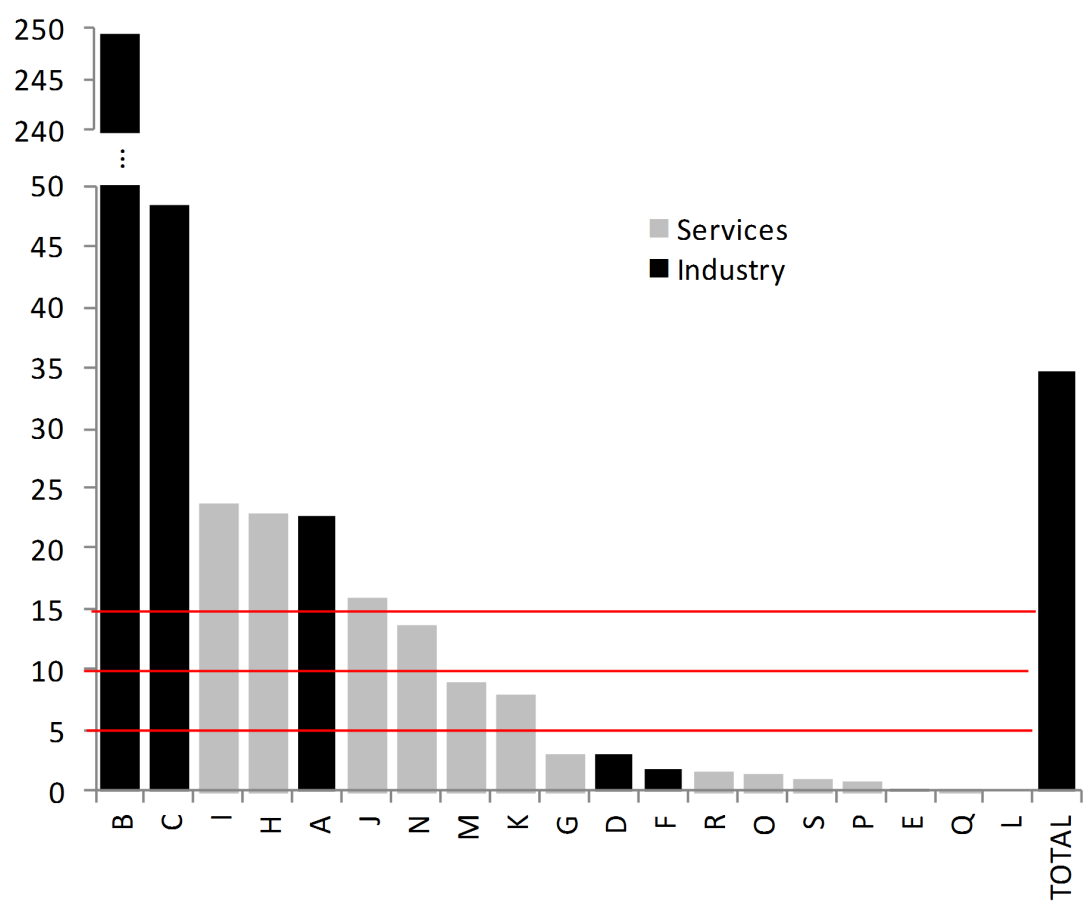

Source: author's calculations using Eurostat, BACI and UN ServiceTrade.

Note: the red lines indicate the 15\%,10\% and 5\% thresholds.

A: Agriculture, forestry and fishing; B: Mining and quarrying; C: Manufacturing; D: Electricity, gas, steam and air conditioning supply; E: Water supply; sewerage, waste management and remediation activities; F: Construction; G: Wholesale and retail trade; repair of motor vehicles and motorcycles; $\mathrm{H}$ : Transportation and storage; I: Accommodation and food service activities; J: Information and communication; K: Financial and insurance activities; L: Real estate activities; M: Professional, scientific and technical activities; N: Administrative and support service activities; O: Public administration and defense; compulsory social security; P: Education; Q: Human health and social work activities; R: Arts, entertainment and recreation; S: Other service activities.

Inevitably, the threshold of $10 \%$ is arbitrary. One possibility could be to apply different tradability criteria for different countries, but applying the same criterion for all countries leads to more clearcut results. ${ }^{9}$ Using a threshold of $15 \%$ would exclude administrative and support service activities from the tradable sector. The tradable sector would then account for $43 \%$ of total production and $32 \%$ of GVA (at current prices), and 33\% of employment. Using a threshold of $5 \%$ would include 2 other sectors in the tradable sector, and more particularly financial and insurance activities. The tradable sector would then account for $57 \%$ of total production and $47 \%$ of GVA (at current prices), and $47 \%$ of employment (see Figure A.1 in the Appendix).

However, for financial and insurance activities for example, recent empirical work (Jensen and Kletzer, 2005; Gervais and Jensen, 2013) shows that financial and insurance activities are heterogenous

\footnotetext{
${ }^{9}$ At country-level, tradability could be affected by market regulations or market structure, which should not matter for the EA11 since tradable sectors are well integrated in Europe (Estrada et al., 2013).
} 
and contain both tradable and non-tradable activities. ${ }^{10}$ Therefore, labeling this sector as tradable or non-tradable is not straightforward. A few authors show the deep linkages between the non-tradable sector expansion and the banking and financial activity (see, for example, Sy, 2016), supporting the assumption of considering financial and insurance activities as non-tradable. As the choice of a $10 \%$ threshold is arbitrary, the $15 \%$ and $5 \%$ thresholds will be used to check the robustness of the empirical results.

\subsection{Stylized facts: the drift from the tradable to the non-tradable sector}

Figure 3 describes the evolution of gross value added, employment and prices in the non-tradable sector relative to the tradable sector, for each country of the EA11, for two subperiods: 1995-2008 and 2008-2013. ${ }^{11}$ The 10\% threshold is used to classify each sector as tradable or not, but similar figures using other thresholds are reported in Appendix. Relative prices are measured as the ratio of non-tradable to the tradable price in the EA $11 .{ }^{12}$

Figures 4 and 5 report the contribution of each sector to the average price and employment growth over the two sub-periods: $1995-2008$ and 2008-2013. Contributions to price growth are measured as the average inflation over the period in the considered sector weighted by its share in total GVA in volume at the initial year (1995 or 2008). Contributions to employment growth are measured as the average employment growth in the considered sector weighted by its share in total employment in thousands of hours at the initial year (1995 or 2008).

Figure 3, for the first sub-period (1995-2008), highlights the similar pattern in all peripheral countries: the hypertrophy of the non-tradable sector. This pattern is also striking when using other thresholds for the measurement of tradability. Prices in the non-tradable sector relative to the tradable sector rose sharply between 1995 and 2008 in Ireland, Italy, Portugal, Spain and Greece. The rise in relative prices and the growing share of the non-tradable sector led to a strong rise in overall prices and wages. However, some differences remain among the peripheral countries.

As Giavazzi and Spaventa (2011) have noted already, relative employment in Greece rose faster than relative GVA at current prices. The country faced a relatively smaller bubble in the housing sector (F-L) than Spain, with the housing sector contributing to 6p.p. of the average inflation over 1995-2008 (Figure 4). The main contributor to inflation and employment growth over 1995-2008 was the public, education and health sector $\left(O_{-} Q\right)$, contributing to respectively 4p.p. of the average employment growth (Figure 5) and 9p.p. of the average GVA deflator growth.

In Portugal, the non-tradable price increase was also led by both the housing and the public, education and health sectors, contributing respectively to 8p.p. and 9p.p. of the average inflation and 1p.p. and 3p.p. of average employment growth over 1995-2008. Employment decreased on

\footnotetext{
${ }^{10}$ These authors use the geographic concentration of activity as a proxy for the tradability of the industry. The more concentrated the activity, the higher its tradability. Applying this methodology on data on U.S. establishments, Gervais and Jensen show that the financial and business services sector has industries in both the top 5 most concentrated and least concentrated manufacturing and business services industries.

${ }^{11}$ As seen on Figure 1, the trends of relative prices and real interest rates started to reverse after the 2008-crisis. We thus use the year 2008 as a break point for the stylized facts presented in this section.

${ }^{12}$ Like in the model and the following empirical analysis, the law of one price is assumed to hold in the tradable sector of the EA and the same tradable EA price is used as the numeraire for the 11 countries. The database used does not inform on price levels, but recent work show empirical evidence of a substantial convergence in price levels in the case of tradable goods (see Estrada et al., 2013). As the main focus of the paper is on the dynamics of the non-tradable sector, we assume the LOP holds and exclude from the analysis the dynamics specific to the tradable sectors.
} 
Figure 3 - Evolution of the non-tradable relative to the tradable sector, $\%$

(a) $2008 / 1995$

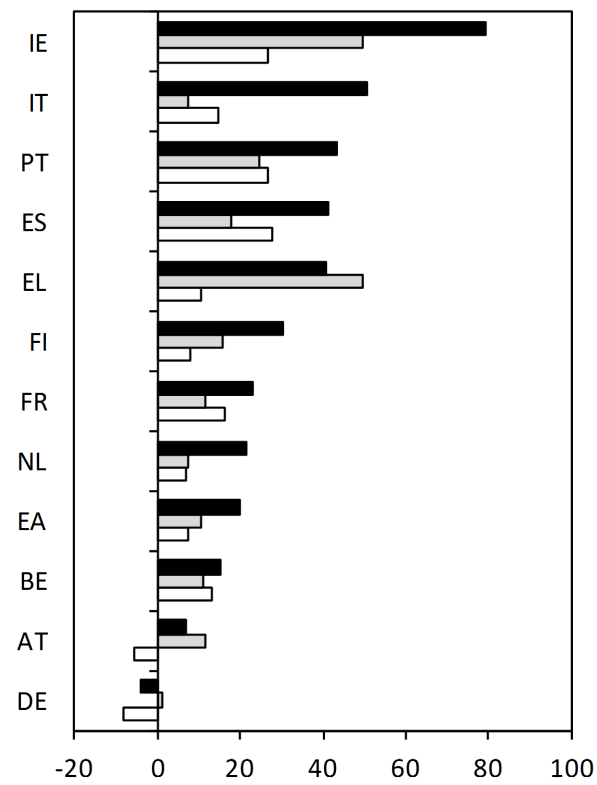

(b) $2013 / 2008$

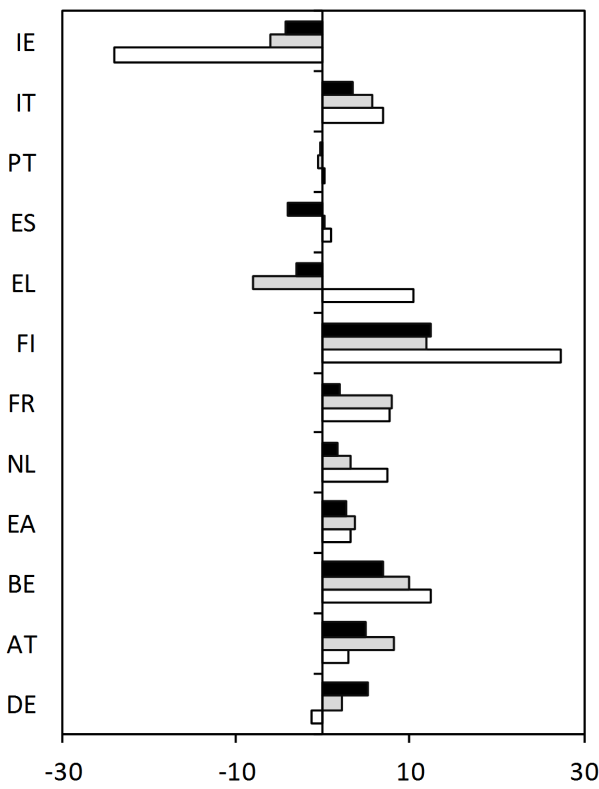

- GVA deflator 口Employment 口GVA at currentprices

Source: author's calculations using Eurostat, BACI and UN ServiceTrade.

Note: relative prices are measured using the $10 \%$ threshold for tradability and are the ratio of nontradable prices relative to the tradable price of the EA11. Employment is measured in thousands of hours worked.

average in the tradable sector -and especially for the industrial and agricultural activities (A_C) which had a negative contribution of -6p.p. to total employment growth.

Ireland and Spain were the two countries with the fastest employment growth over 1995-2008, both experiencing a housing bubble: the housing sector contribution to the average growth employment over the period reached 5p.p. and 6p.p. respectively. In Ireland, employment growth was also led by the expansion of the public, education and health sector. In Spain, the housing sector also contributed to a 8p.p. increase in the average inflation, and was by far the main contributor to price growth over 1995-2008. 
Figure 4 - GVA deflators: contributions of each sector to average growth over 1995-2008 and 20082013, by country

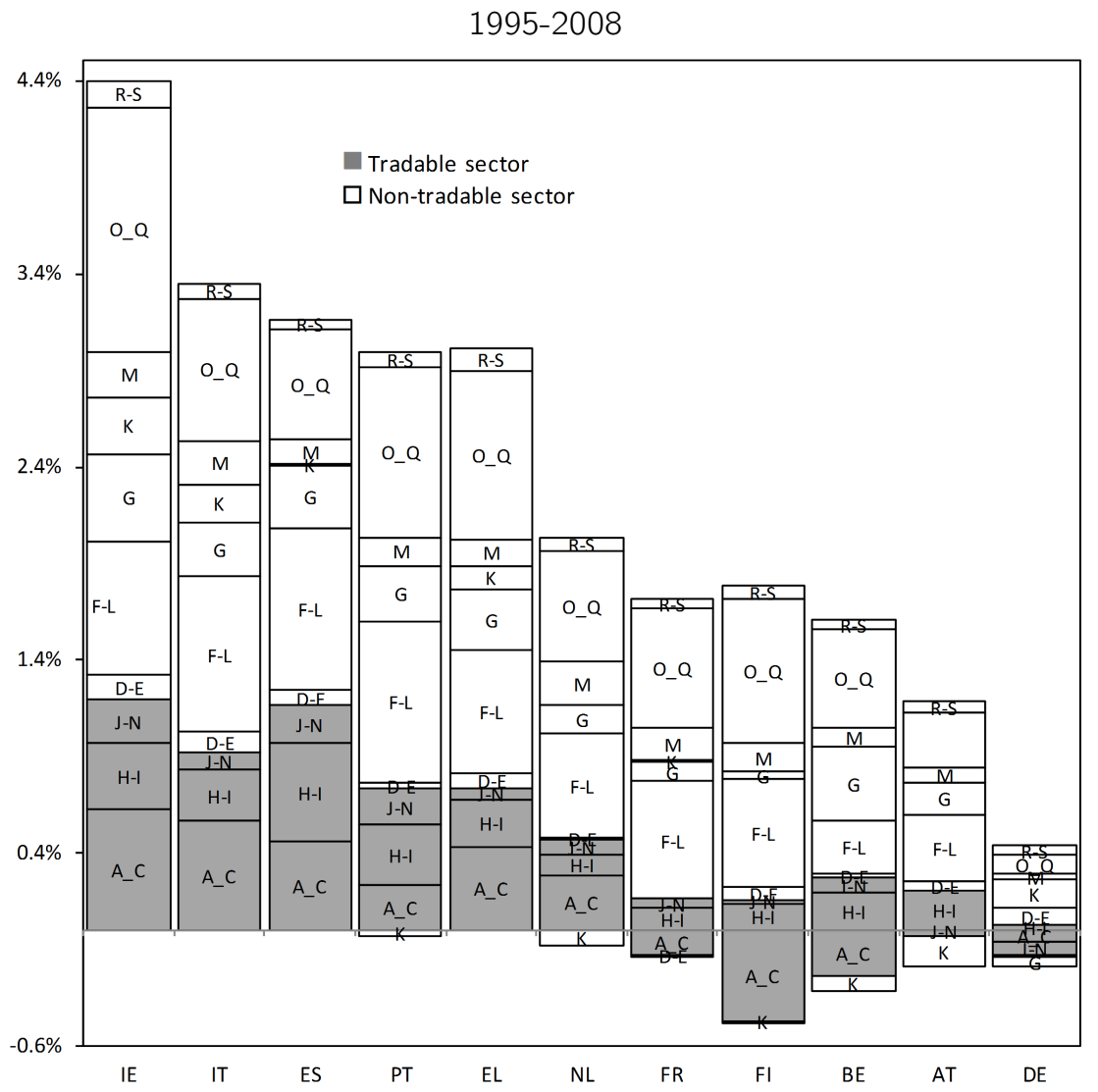

$2008-2013$

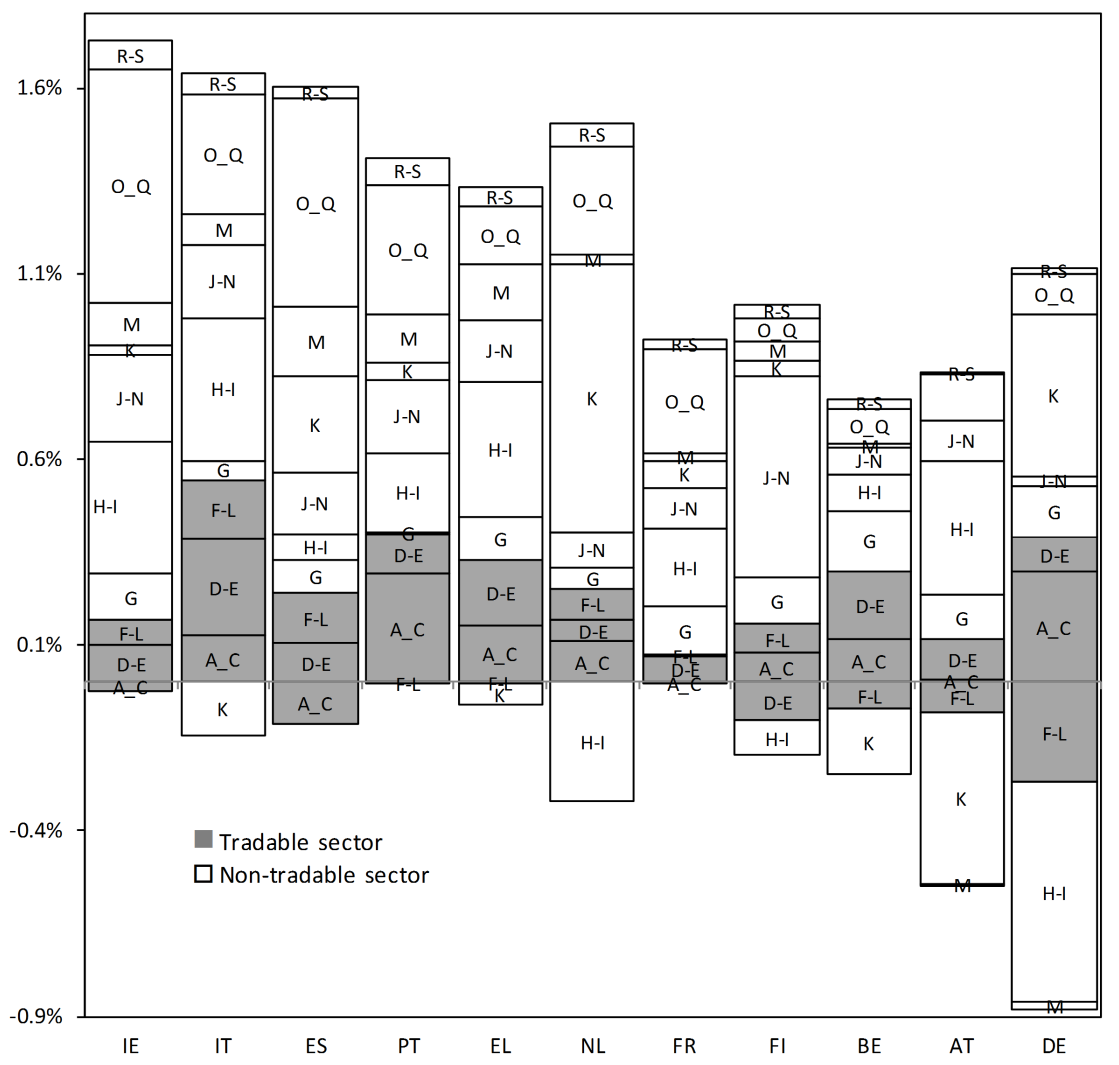

Source: author's calculations using Eurostat, BACl, UN ServiceTrade. Note: chained-linked indices, reference year: 1995. For the measurement of the tradability of each sector, the $10 \%$ threshold is used.

A_C: tradable industry; $\mathrm{H}-\mathrm{I}$ : transportation, accommodation \& food service activities; J-N: other tradable service activities; D-E: non-tradable industry; F-L: construction \& real estate; G: wholesale and retail trade; K: finance \& insurance services; M: other non-tradable business services; O Q: public administration, education, health and social work activities; R-S: other non-tradable services. 
Figure 5 - Employment: contributions of each sector to average growth over 1995-2008 and 20082013, by country

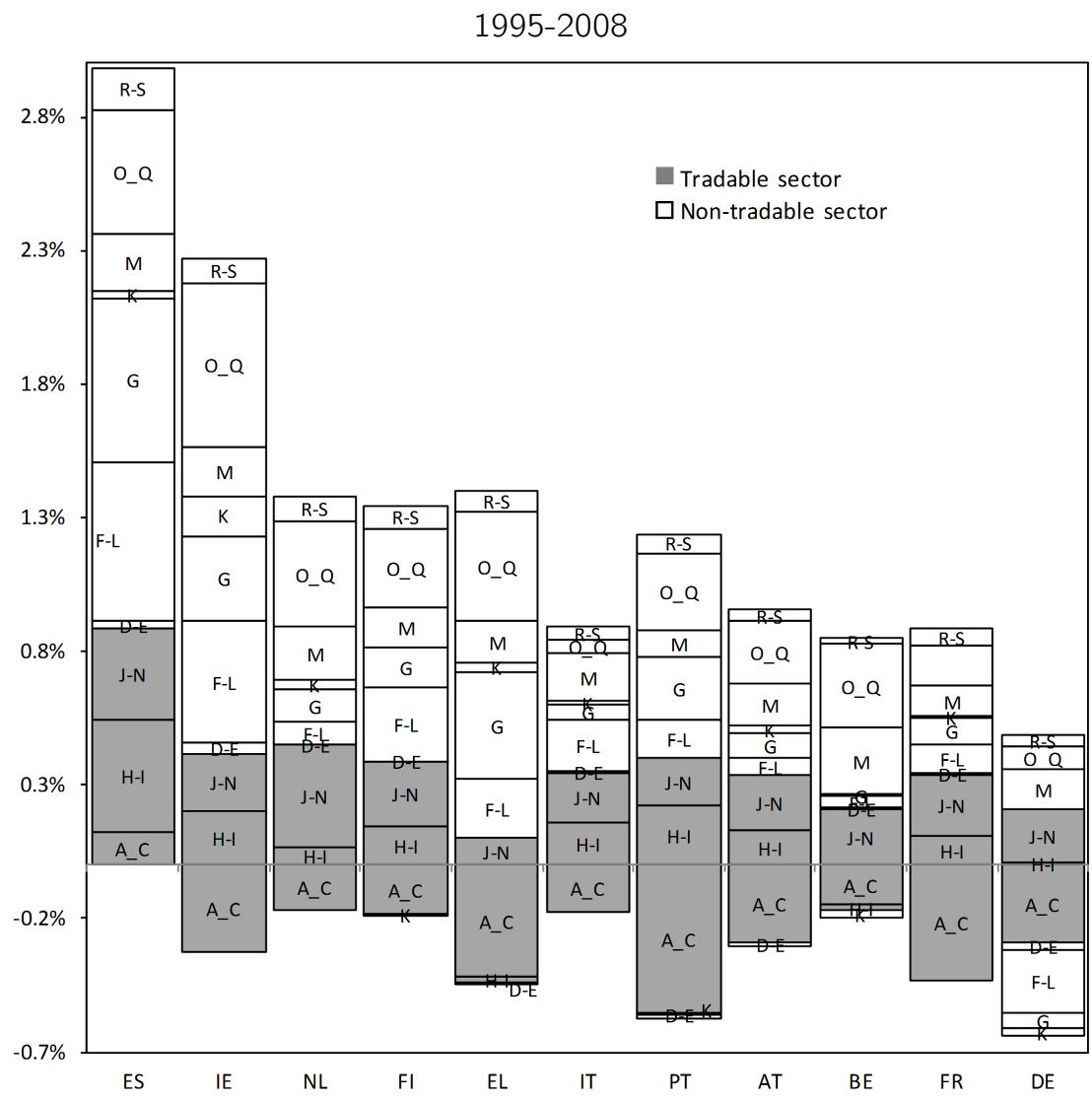

$2008-2013$

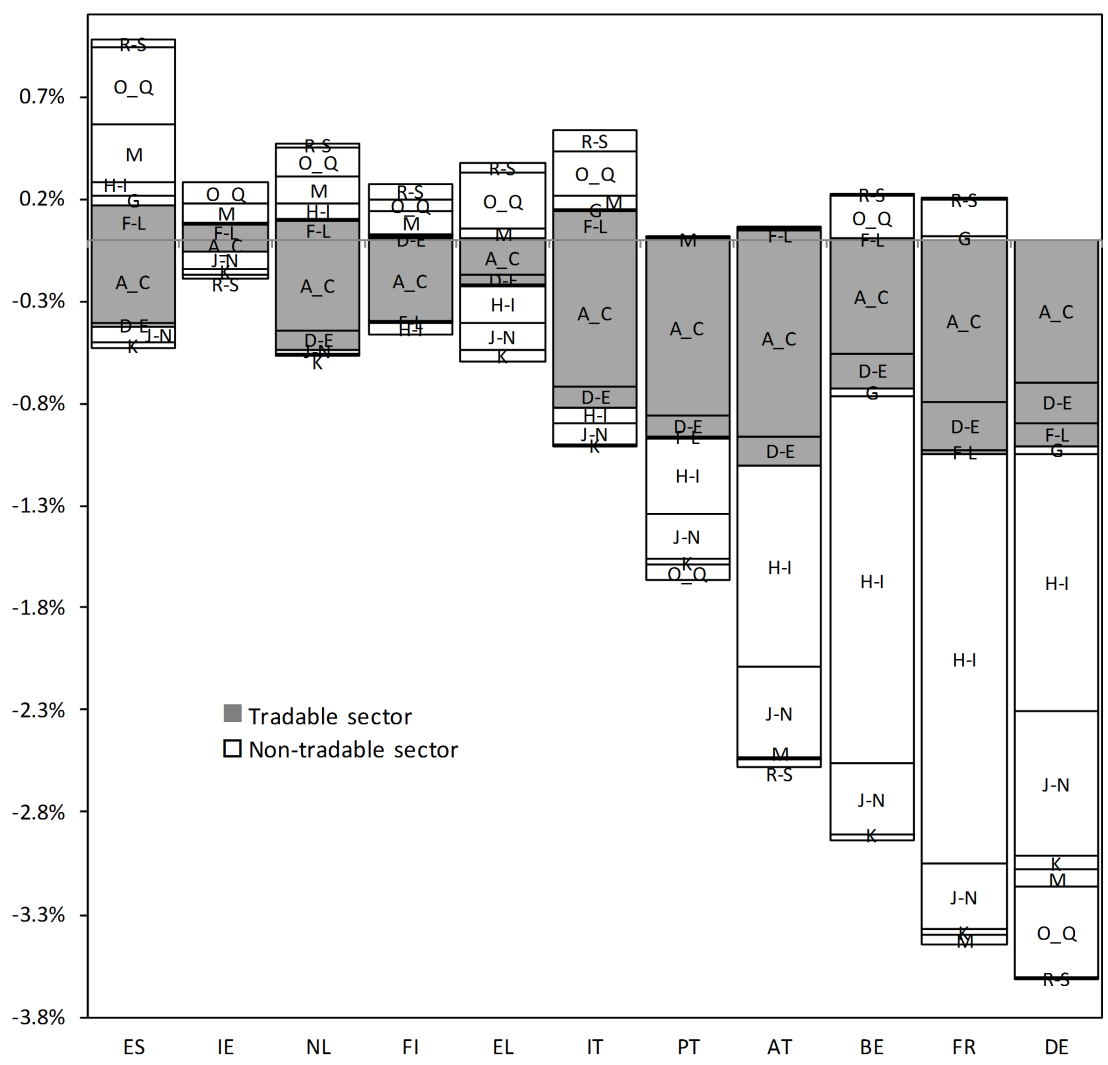

Source: author's calculations using Eurostat, BACl, UN ServiceTrade. Note: thousands of hours worked. For the measurement of the tradability of each sector, the $10 \%$ threshold is used.

A_C: tradable industry; $\mathrm{H}-\mathrm{I}$ : transportation, accommodation \& food service activities; J-N: other tradable service activities; D-E: non-tradable industry; F-L: construction \& real estate; G: wholesale and retail trade; K: finance \& insurance services; M: other non-tradable business services; O_Q: public administration, education, health and social work activities; R-S: other non-tradable services. 
The evolution of the relative price of non-tradables seems to be well correlated to current account deficits: countries facing the steepest increase in prices have the largest deficits over 1995-2008. Since capital inflows did not serve to expand the tradable sector, however, when facing sudden stops, countries were forced to readjust and reallocate their factors of production to the tradable sector in order to produce the tradable surplus necessary to reimburse foreign liabilities previously accumulated. As we see in Figure 3, relative prices decreased in the peripheral countries relatively more than in the rest of the EA11 over 2008-2013. These adjustments happened at a high social cost. In Spain and Greece, in particular, the readjustment resulted in a steep increase in unemployment. Wages fell by $16 \%$ in Greece, $5 \%$ in Ireland, remained stable in Portugal and slowed down in Spain between 2008 and 2013.

\section{Determinants of the relative price of non-tradables}

This section presents empirical evidence supporting the theoretical result that the real interest rate, together with the traditional BS effect, impact the evolution of non-tradable prices. To do so, it uses the data gathered on the evolution of non-tradable relative prices, apparent labor productivity in the tradable sector and real interest rates. ${ }^{13}$ All variables are expressed in deviations from the EA11 average. The choice of a reference here is neutral since all estimations are performed in logarithms.

The sample ranges from 1995 to 2013 and covers $N=11$ EA countries, which amounts to $T=19$ observations per country. In terms of size, the sample is close to previous studies of the BS effect, for instance De Gregorio et al. (1994) use data for 14 OECD countries over 1970-1985 (16 observations per country), or Bénassy-Quéré and Coulibaly (2014) use a dataset including 12 European countries over 1985-2006 (21 observations per country).

Figure 6 displays non-tradable prices, real interest rates and apparent labor productivity in the tradable sector, over 1995-2013, in core and periphery countries (weighted averages; the figures for each countries are presented in Appendix). The figures highlight both the BS effect and the real interest rate effects analyzed earlier: in the periphery for example, real interest rates declined by about $1.0 \%$ over 1995-2008 compared to the EA average, while non-tradable relative prices increase by $12.2 \%$ and productivity in the tradable sector increased $(25.0 \%)$ compared to the EA average. In core countries, real interest rates increased by $0.3 \%$ over $1995-2008$ relatively to the EA average, while non-tradable prices and tradable productivity decreased by $17.6 \%$ and $13.3 \%$ respectively, relatively to the EA average (numbers are also given in Table 5).

To deal with data limitations, panel techniques are used to estimate equation (6). With nonstationary series, equation (6) needs to be a cointegration relationship, as is usually the case in the BS framework. Therefore, before estimating equation (6), panel unit root tests and tests for the existence of a cointegration relationship are performed. ${ }^{14}$ The presence of structural breaks will be tested, as the sample covers both the adoption of the common currency and the 2010 euro crisis.

For robustness, all tests and estimations are performed using the 5\% and $15 \%$ thresholds value for the measure of tradability. Estimates will also be provided for a sample excluding the real estate

\footnotetext{
${ }^{13} \mathrm{~A}$ 2-year moving average (average of the value in $t$ and $t-1$ ) for the interest rate is used to capture the inertia of capital adjustment and its consecutive effect on the relative price.

${ }^{14}$ The tests are performed with GAUSS, using the codes provided by J. Westerlund, J.L. Carrion-i-Silvestre and N.C. Mark \& D. Sul.
} 
Figure $\mathbf{6}$ - Non-tradable prices, productivity in the tradable sector and long-term real interest rate in core and periphery countries 1995-2013, log deviations from the EA11 average

Core countries

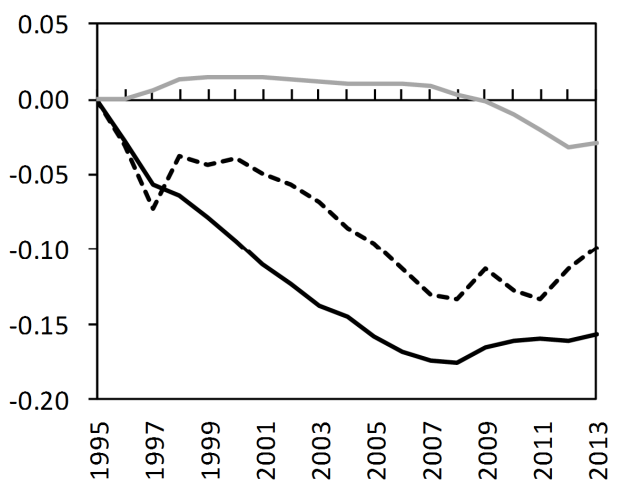

Periphery

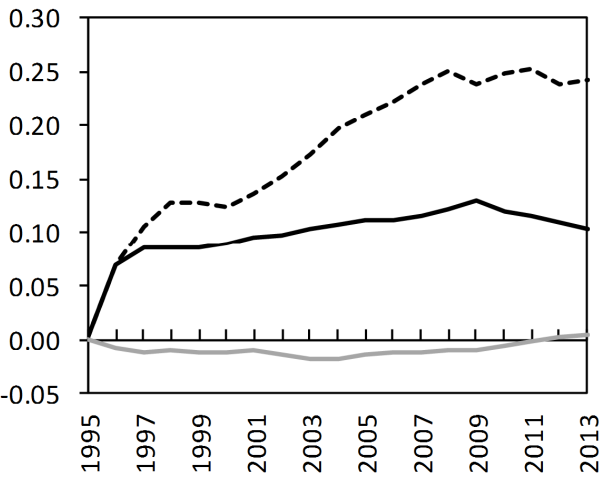

- Non-tradable prices

---Productivity in the tradable sector

- Real interest rate

Source: author's calculations using Eurostat, BACl and UN ServiceTrade and Ameco.

Note: non-tradable prices and productivity in the tradable sector are measured using the $10 \%$ threshold for tradability. The real interest rate is a 2-year moving average. Variables for each group are weighted averages (weight: gross value added at current prices).

and construction sectors, to check if results do not reflecting only the specificity of the housing sector. To be sure that demand factors play a limited role in the long-run, we also control for demand effects. Finally, estimates are provided for a sample covering the shorter period 1995-2009 to see if results are relevant when not taking into account the 2010 euro crisis.

\subsection{Panel unit root and cointegration tests}

The presence of unit roots in the series is studied using the third generation panel unit root test of Bai and Carrion-i-Silvestre (2009), allowing for heterogeneous panels with cross-section dependence and multiple structural breaks. The case for cross-section dependence is especially relevant here since real interest rate divergence resulted from nominal interest rate convergence in the euro area around the euro's inception. This test allows also the presence of multiple structural breaks, which number and dates are unknown and heterogeneous across countries. These shifts can affect both the level and the slope of each time series. Allowing for structural breaks is important in the analysis since the sample covers both the adoption of the common currency and the 2010 euro crisis.

This test has a null hypothesis of a unit root. More precisely, after identifying and taking into account the number and locations of structural breaks for each series (identified using the sequential procedure in Bai and Perron, 1998) and the common factors (estimated using the BIC criterion), this test pools modified Sargan-Bhargava (MSB) tests for individuals series. Three different pooling methods are used resulting in three different test statistics: $Z$, a standardization of individual statistics, and $P$ and $P_{m}$ combining their $p$-values. When shifts in trends are present, a simplified MSB test is also performed on individual series, adding three other pooled statistics : $Z^{*}, P^{*}$ and 
$P_{m}^{*}$. Monte Carlo simulations confirm the good performance of the tests in finite samples (see Bai and Carrion-i-Silvestre, 2009).

Up to two structural breaks are found for each country time series, and one on average for each of the 3 variables (relative price, productivity in the tradable sector and real interest rate). ${ }^{15}$ Results are presented in Table 1. It can be concluded that at conventional levels of significance, all series are non-stationary.

Cointegration tests are then performed. We use the third generation test proposed by Westerlund and Edgerton (2008), which allows for heterogeneous specifications in both the long and short run parts of the error correction model, based on the data. It also takes into account crosssection dependence and unknown structural breaks in both the mean and slope of the cointegrated regression. The authors suggest two simple tests for the null hypothesis of no cointegration derived from the Lagrange multiplier (LM) based unit root tests: the coefficient version $\left(\phi_{N}\right)$ and the t-test version $\left(\tau_{N}\right)$. Three different options are presented: the case with no break, the case with a shift in level only, and the case with a shift in level and trend. The tests generally perform well even in small samples.

Table 2 give the results of the tests: the two statistics reject the null hypothesis of no cointegration at the $10 \%$ level of significance in every case, aside from the $\tau_{N}$ statistic in the model with no shift.

\subsection{Estimation of the long-run relationship}

The long-run relationship is estimated using panel Dynamic OLS (DOLS) techniques. Two main approaches have been proposed in the literature that both deal with serial correlation and the endogeneity of the regressors: the fulled modified ordinary least squares (FMOLS) and the dynamic ordinary least squares (DOLS). The DOLS procedure consists in estimating a long-run relationship by instrumental variables using leads and lags of the differenced endogenous variables as instruments. Kao and Chiang (2001) show that DOLS outperform both OLS and FMOLS estimators in estimating cointegrated panel regressions. We use the extension to the DOLS framework suggested by Mark and Sul (2003), which allows for individual heterogeneity through different short-run dynamics, individual-specific fixed effects and individual-specific time trends.

The empirical model corresponding to equation (6) is:

$$
\ln \left(\frac{p_{N, i, t}}{p_{N, E A, t}}\right)=\eta_{i}+\gamma_{i} t+\mu_{t}+\beta_{1} \ln \left(\frac{A_{T, i, t}}{A_{T, E A, t}}\right)+\beta_{2} \ln \left(\frac{1+r_{i, t}}{1+r_{E A, t}}\right)+\varepsilon_{i, t}
$$

where $\eta_{i}$ and $\gamma_{i} t$ are country-specific fixed effects and trends, $\mu_{t}$ is a common-time effect, and $\varepsilon_{i, t}$ is the idiosyncratic error.

Table 3 report the estimation for the single BS effect (columns 1 and 3 ), and of the BS and real interest rate effects (columns 2 and 4). For robustness, a first estimation is implemented with country-specific fixed effects and trends (columns 1 and 2), while the second also includes a common-time effect (columns 3 and 4).

\footnotetext{
${ }^{15}$ The break is most recurrent in 2010 for the relative price, 1998 for the productivity in the tradable sector and 2007 for the real interest rate.
} 
Table 1 - Third generation panel unit root tests

\begin{tabular}{|c|c|c|c|}
\hline & $\ln \left(\frac{p_{N}}{p_{N, E A}}\right)$ & $\ln \left(\frac{A_{T}}{A_{T, E A}}\right)$ & $\ln \left(\frac{1+r}{1+r_{E A}}\right)$ \\
\hline \multicolumn{4}{|c|}{ Constant and trend (no break) } \\
\hline$Z$ & -1.370 & -0.689 & -0.367 \\
\hline$P_{m}$ & 0.247 & 0.749 & -1.163 \\
\hline$P$ & 23.640 & 26.967 & 14.286 \\
\hline \multicolumn{4}{|c|}{ Trend shifts } \\
\hline$Z$ & 0.758 & 0.157 & 0.058 \\
\hline$P_{m}$ & -0.818 & -0.002 & -1.460 \\
\hline$P$ & 16.572 & 21.99 & 12.313 \\
\hline$Z *$ & 2.152 & 0.996 & 0.051 \\
\hline$P_{m} *$ & -1.429 & -0.028 & -0.985 \\
\hline$P *$ & 12.522 & 21.815 & 15.465 \\
\hline
\end{tabular}

Note: the test has a null hypothesis of a unit root. Country-specific intercepts and trends are included (model 2). See Bai and Carrion-i-Silvestre (2009) for a description of the tests. The 1\%, 5\% and 10\% critical values for the absolute value of the standard normal distributed $Z$ and $P_{m}$ statistics are 2.326, 1.645 and 1.282 , while the critical values for the chi-squared distributed $P$ statistic are $40.289,33.924$ and 30.813 , respectively. The number of common factors are estimated using the panel Bayesian information criterion proposed by Bai and $\mathrm{Ng}$ (2002), and the test was estimated with a maximum number of breaks of 3.

Source: author's calculations.

Table 2 - Third generation panel cointegration test of Westerlund and Edgerton (2008)

\begin{tabular}{|l|cc|cc|}
\cline { 2 - 5 } \multicolumn{1}{c|}{} & \multicolumn{2}{c|}{$\tau_{N}$} & \multicolumn{2}{c|}{$\phi_{N}$} \\
\cline { 2 - 5 } \multicolumn{1}{c|}{} & value & $p$-value & value & $p$-value \\
\hline No shift & -1.373 & 0.085 & -0.673 & 0.250 \\
\hline Level shift & -4.137 & 0.000 & -2.422 & 0.008 \\
\hline Regime shift & -6.99 & 0.000 & -4.358 & 0.000 \\
\hline
\end{tabular}

Note: the test has the null hypothesis of no-cointegration. The breaks are determined by grid search at the minimum of the sum of squared residuals. The $p$-values are for one-sided test based on the normal distribution.

Source: author's calculations. 
Table 3 - Panel cointegration estimates of the Balassa-Samuelson and real interest rate effects

\begin{tabular}{|c|cc|cc|}
\multicolumn{4}{c|}{ Dependent variable : $\ln \left(\frac{p_{N}}{p_{N, E A}}\right), 1995-2013$} \\
\cline { 2 - 5 } \multicolumn{1}{c|}{} & No common time effect $\left(\mu_{t}\right)$ & \multicolumn{2}{c|}{ Common time effect $\left(\mu_{t}\right)$} \\
\hline $\ln \left(\frac{A_{T}}{A_{T, E A}}\right)$ & $(1)$ & $(2)$ & $(3)$ & $(4)$ \\
& $0.611^{* * *}$ & $0.360^{* * *}$ & $0.659 * * *$ & $0.410^{* * *}$ \\
& $(0.126)$ & $(0.130)$ & $(0.132)$ & $(0.135)$ \\
\hline $\ln \left(\frac{1+r}{1+r_{E A}}\right)$ & & $-1.287 * * *$ & & $-1.186 * * *$ \\
& & $(0.360)$ & & $(0.376)$ \\
\hline
\end{tabular}

Note: standard errors, in parentheses, are based on Andrews and Monathan (1992) pre-whitening method. $*, * *$ and $* * *$ denote significance at $10 \%, 5 \%$ and $1 \%$ levels respectively.

Source: author's calculations.

It appears that both explanatory variables (tradable productivity and real interest rate, in deviations from the EA average) are significant at the $1 \%$ level and have the expected sign. A $+1 \%$ differential in the tradable sector productivity raises the non-tradable price by $0.36 \%$ to $0.66 \%$ relative to the EA average. Introducing the real interest rate tends to depress the coefficient of the BS effect using the samples covering the 1995-2013 period.

A $+1 \%$ differential in the real interest rate reduces the non-tradable price by $1.19 \%$ to $1.29 \%$ relative to the EA average. It thus seems that diverging evolution in the interest rate impacted greatly the evolution of non-tradable relative prices within the euro area over the period.

\subsection{Robustness tests}

Different thresholds for the measure of tradability For robustness, all tests and estimations are now performed using the $5 \%$ and $15 \%$ thresholds value for the measure of tradability. We first test for the presence of unit roots in the series using the third generation panel unit root test of Bai and Carrion-i-Silvestre (2009). Structural breaks are found again for every variable. There are up to two structural breaks for each time series, and one on average. Results for the tests are presented in Appendix (Table A.2). It can be concluded that at conventional levels of significance, all series are non-stationary. ${ }^{16}$

Cointegration tests are then performed for series that are non-stationary using test proposed by Westerlund and Edgerton (2008). Three different options are presented: the case with no break, the case with a shift in level only, and the case with a shift in level and trend. Table A.3 in the Appendix gives the results of the tests: the two statistics reject the null hypothesis of no cointegration at the $10 \%$ level of significance in every case, expect the $\tau_{N}$ statistic in the model with a regime shift for the $5 \%$ threshold, and with no shift for the $15 \%$ threshold.

As all three series, measured using different thresholds (5\% and 15\%), are non-stationary and cointegrated, panel DOLS estimations of equation are performed to estimate equation (6). Table 4a reports the estimation for the single BS effect (columns 1 and 3), and of the BS and real interest

\footnotetext{
${ }^{16}$ Only the $Z$ statistic for the tests driven for non-tradable prices present mixed results.
} 
rate effects (columns 2 and 4). For robustness, a first estimation is implemented with countryspecific fixed effects and trends (columns 1 and 2), while the second also includes a common-time effect (columns 3 and 4). It appears that both explanatory variables (tradable productivity and real interest rate, in deviations from the EA average) are significant at the $1 \%$ level and have the expected sign using the two samples with different thresholds for the measure of tradability ( $5 \%$ and $15 \%)$.

Excluding the housing sector All tests and estimations are also performed excluding the housing sector (Nace codes $C$ and L) from the dataset. In this case also it can be concluded that at conventional levels of significance, all series are non-stationary and cointegrated (see Table A.3 in Appendix). ${ }^{17}$ Panel DOLS estimates are very close to the case where the housing sector is included (Table 4b).

Controlling for demand effects Demand booms and busts could have lasting effects on relative prices. To control for these effects, we include real domestic consumption (in deviations from the EA average, measured using data from Ameco) in the previous tests and estimations. At conventional levels of significance, real domestic consumption is non-stationary. However, when including it in the cointegration analysis, the four series are no longer cointegrated (see Table A.3 in Appendix $)^{18}$. Panel DOLS estimates confirm the fact that demand factors do not play a significant role in the long-run: when including real domestic demand in the equation, this variable is not significant. Tradable productivity and real interest rate are still significant at the $1 \%$ level and have the expected sign, their coefficients are slightly reduced (see Table 4c). Demand effects should thus play mainly in the short-run dynamics of relative prices.

Excluding the Euro crisis Estimates are also provided for a sample covering the shorter period 1995-2009 to see if results are relevant when not taking into account the 2010 euro crisis (see Table 4d).

In this sample covering a shorter time period, tradable productivity is not significant when introduced alone. We can see that the impact of a $+1 \%$ differential in the tradable sector productivity raises the non-tradable price by $0.26 \%$ to $0.72 \%$ relative to the EA average. Introducing the real interest rate tends to depress the coefficient of the BS effect using the samples covering the 1995-2013 period, but increase the coefficient using the sample covering the $1995-2009$ period. A $+1 \%$ real interest rate differential reduces the non-tradable price by $0.99 \%$ to $1.52 \%$ relative to the $E A$ average.

Overall, the impact of a $+1 \%$ differential in the real interest rate reduces the non-tradable price by $0.86 \%$ to $1.52 \%$ relative to the EA. It thus seems that diverging evolution in the interest rate impacted greatly the evolution of non-tradable relative prices within the euro area over the period. In periphery countries, over 1995-2008, changes in the interest rate could explain up to $13 \%$ of the changes in relative prices. In Greece, the fall in the real interest rate over 1995-2008 could

\footnotetext{
${ }^{17}$ When taking into account the existence of a trend shift, results are weaker when testing the non-stationarity of non-tradable prices.

${ }^{18}$ Real consumption, tradable productivity, and relative prices are not cointegrated either when excluding the real interest rate. Results are not reported for this case.
} 
A European Disease? Non-tradable inflation and real interest rate divergence Table 4 - Panel cointegration estimates: robustness tests

Dependent variable : $\ln \left(\frac{p_{N}}{p_{N, E A}}\right)$

(a) using different measures of tradability

\begin{tabular}{|c|cc|cc|}
\cline { 2 - 5 } \multicolumn{1}{c|}{} & $\begin{array}{c}\text { No common time effect }\left(\mu_{t}\right) \\
(1)\end{array}$ & $\begin{array}{c}\text { Common time effect }\left(\mu_{t}\right) \\
(2)\end{array}$ & $(4)$ \\
\hline $\ln \left(\frac{A_{T}}{A_{T, E A}}\right)$ & $0.650^{* * *}$ & $0.404^{* * *}$ & $0.722^{* * *}$ & $0.458^{* * *}$ \\
& $(0.125)$ & $(0.106)$ & $(0.137)$ & $(0.113)$ \\
\hline $\ln \left(\frac{1+r}{1+r_{E A}}\right)$ & $-1.181^{* * *}$ & & $-0.994^{* * *}$ \\
& $(0.353)$ & $(0.360)$ \\
\hline $\operatorname{c} 15 \%$ threshold \\
\hline $\ln \left(\frac{A_{T}}{A_{T, E A}}\right)$ & $0.550^{* * *}$ & $0.406^{* * *}$ & $0.605^{* * *}$ & $0.461^{* * *}$ \\
& $(0.179)$ & $(0.130)$ & $(0.195)$ & $(0.138)$ \\
\hline $\ln \left(\frac{1+r}{1+r_{E A}}\right)$ & $-1.260^{* * *}$ & & $-1.135^{* * *}$ \\
& $(0.357)$ & $0.373)$ \\
\hline
\end{tabular}

(b) excluding the housing sector

\begin{tabular}{|c|cc|cc|}
\cline { 2 - 5 } \multicolumn{1}{c|}{} & \multicolumn{2}{|c|}{ No common time effect $\left(\mu_{t}\right)$} & \multicolumn{2}{c|}{ Common time effect $\left(\mu_{t}\right)$} \\
& $(1)$ & $(2)$ & $(3)$ & $(4)$ \\
\hline $\ln \left(\frac{A_{T}}{A_{T, E A}}\right)$ & $0.717^{* * *}$ & $0.511^{* * *}$ & $0.769^{* * *}$ & $0.569^{* * *}$ \\
& $(0.156)$ & $(0.185)$ & $(0.169)$ & $(0.191)$ \\
\hline $\ln \left(\frac{1+r}{1+r_{E A}}\right)$ & & $-1.192^{* * *}$ & & $-1.093^{* *}$ \\
& & $(0.495)$ & & $(0.517)$ \\
\hline
\end{tabular}

(c) controlling for demand

\begin{tabular}{|c|ccc|ccc|}
\cline { 2 - 7 } \multicolumn{1}{c|}{} & \multicolumn{3}{c|}{ No common time effect $\left(\mu_{t}\right)$} & \multicolumn{3}{c|}{ Common time effect $\left(\mu_{t}\right)$} \\
& $(1)$ & $(2)$ & $(3)$ & $(4)$ & $(5)$ & $(6)$ \\
\hline $\ln \left(\frac{A_{T}}{A_{T, E A}}\right)$ & $0.611^{* * *}$ & $0.360^{* * *}$ & $0.340^{* * *}$ & $0.659^{* * *}$ & $0.410^{* * *}$ & $0.347^{* * *}$ \\
& $(0.126)$ & $(0.130)$ & $(0.034)$ & $(0.132)$ & $(0.135)$ & $(0.036)$ \\
\hline $\ln \left(\frac{1+r}{1+r_{E A}}\right)$ & & $-1.287^{* * *}$ & $-0.945^{* * *}$ & & $-1.186^{* * *}$ & $-0.863^{* * *}$ \\
& & $(0.360)$ & $(0.123)$ & & $(0.376)$ & $(0.128)$ \\
\hline $\ln \left(\frac{C}{C_{E A}}\right)$ & & & 0.060 & & & 0.073 \\
& & & $(0.058)$ & & & $0.057)$ \\
\hline
\end{tabular}

(d) using a shorter period: 1995-2009

\begin{tabular}{|c|cc|cc|}
\cline { 2 - 5 } \multicolumn{1}{c|}{} & \multicolumn{2}{|c|}{ No common time effect $\left(\mu_{t}\right)$} & \multicolumn{2}{c|}{ Common time effect $\left(\mu_{t}\right)$} \\
& $(1)$ & $(2)$ & $(3)$ & $(4)$ \\
\hline $\ln \left(\frac{A_{T}}{A_{T, E A}}\right)$ & 0.127 & $0.259^{* * *}$ & 0.147 & $0.284^{* * *}$ \\
& $(0.162)$ & $(0.054)$ & $(0.189)$ & $(0.054)$ \\
\hline $\ln \left(\frac{1+r}{1+r_{E A}}\right)$ & & $-1.521^{* * *}$ & & $-1.494^{* * *}$ \\
& & $(0.282)$ & & $(0.271)$ \\
\hline
\end{tabular}

Note: standard errors, in parentheses, are based on Andrews and Monathan (1992) pre-whitening method. $*, * *$ and $* * *$ denote significance at $10 \%, 5 \%$ and $1 \%$ levels respectively.

Source: author's calculations. 
explain almost half of the non-tradable price increase relative to the EA average, while in Germany the increase in the real interest rate might have contributed up to $7 \%$ of the decrease of the non-tradable price relative to the average of the EA (Table 5).

Table 5 - Contributions of the Balassa Samuelson (BS) and the real interest rate effects to the nontradable price growth

1995-2008, deviations from the EA average

\begin{tabular}{|l||c|c|c||c|c|}
\cline { 2 - 6 } \multicolumn{2}{c||}{} & \multicolumn{3}{c||}{ Growth } & \multicolumn{2}{c|}{$\begin{array}{c}\text { Contributions to non-tradable } \\
\text { price growth }\end{array}$} \\
\cline { 2 - 6 } \multicolumn{1}{c||}{} & $\begin{array}{c}\text { Non-tradable } \\
\text { prices }\end{array}$ & $\begin{array}{c}\text { Productivity in } \\
\text { the tradable sector }\end{array}$ & $\begin{array}{c}\text { Real interest } \\
\text { rates }\end{array}$ & BS effect & $\begin{array}{c}\text { Real interest } \\
\text { rate effect }\end{array}$ \\
\hline AT & $-20.2 \%$ & $-15.3 \%$ & $0.4 \%$ & $-4.0 \%$ & $-0.6 \%$ \\
BE & $-12.4 \%$ & $-7.3 \%$ & $-0.4 \%$ & $-1.9 \%$ & $0.6 \%$ \\
DE & $-30.9 \%$ & $-21.9 \%$ & $1.4 \%$ & $-5.7 \%$ & $-2.1 \%$ \\
EL & $7.6 \%$ & $9.3 \%$ & $-2.3 \%$ & $2.4 \%$ & $3.5 \%$ \\
ES & $7.6 \%$ & $31.5 \%$ & $-1.0 \%$ & $8.1 \%$ & $1.5 \%$ \\
FI & $-0.4 \%$ & $-21.0 \%$ & $0.3 \%$ & $-5.4 \%$ & $-0.5 \%$ \\
FR & $-6.0 \%$ & $-4.7 \%$ & $-1.1 \%$ & $-1.2 \%$ & $1.7 \%$ \\
IE & $31.7 \%$ & $-23.6 \%$ & $3.4 \%$ & $-6.1 \%$ & $-5.2 \%$ \\
IT & $14.1 \%$ & $27.4 \%$ & $-1.4 \%$ & $7.1 \%$ & $2.1 \%$ \\
NL & $-7.3 \%$ & $0.9 \%$ & $0.6 \%$ & $0.2 \%$ & $-0.9 \%$ \\
PT & $9.2 \%$ & $22.0 \%$ & $0.0 \%$ & $5.7 \%$ & $0.0 \%$ \\
\hline Core* & $-17.6 \%$ & $-13.3 \%$ & $0.3 \%$ & $-3.4 \%$ & $-0.5 \%$ \\
Periphery* & $12.2 \%$ & $25.0 \%$ & $-1.0 \%$ & $6.5 \%$ & $1.6 \%$ \\
\hline
\end{tabular}

*weighted averages, weight: gross value added at current prices.

Source: author's calculations.

Note: contributions are measured using the coefficients resulting from panel DOLS estimates with no common time effect on the sample covering the 1995-2009 periods and using the 10\% threshold for the measure of tradability, see Table 4d, 3rd estimate, column (2). For example, in Greece (EL), the real interest rate contribution to the non-tradable price increase is: $(-2.3) *(-1.521)=3.5 \%$. Therefore, the real interest rate fall in Greece could explain 3.5/7.6 $=46 \%$ of the non-tradable price increase over 1995-2008 relative to the EA11. 


\section{Concluding Remarks}

This paper has analyzed how the real interest rate influences the dynamics of non-tradable relative prices. The theoretical framework, incorporating two factors of production in the traditional Balassa-Samuelson model, shows that the real interest rate fall in the euro area periphery following the single currency's inception induced an increase in the relative price of non-tradable goods. The paper then documents the dynamics of the tradable to the non-tradable sector over 1995-2013 using a new dataset and carries out an econometric estimation for 11 EA countries to quantify the contribution of the pure Balassa-Samuelson effect and the impact of the interest rate on non-tradable relative prices.

The results confirm that, together with the traditional BS effect, diverging evolutions in real interest rates seem to have contributed to the evolution of non-tradable relative prices within the euro area over the period. In Greece, the fall in the real interest rate over 1995-2008 could explain almost half of the non-tradable price increase relative to the EA average, while in Germany the increase in the real interest rate might have contributed up to $7 \%$ of the decrease of the non-tradable price relative to the average of the EA.

This result is especially important in the context of the debate on the relative price adjustment and the subsequent surveillance within Europe. Divergence across euro area members challenges greatly the efficiency of a single monetary policy. This divergence was translated, before the crisis, in strong inflation differentials as we have seen. While the introduction of the euro should have fostered a real convergence as capital flew towards so-called "catching-up" economies, these capital flows were indeed mainly allocated in the less innovative non-tradable sectors and fueled strong price increases. Since the 2008 financial crisis, in the EA periphery, increased interest rates may have contributed to internal rebalancing but labor reallocation happens at a high social cost as the non-tradable sector is more labor-intensive than the tradable sector. The divergence thus now takes the form of strong heterogeneities in how economies reacted to the financial crisis, and through high differentials in unemployment rates across countries. 


\section{References}

Andrews, D. and Monathan, J. (1992). An improved heteroskedasticity and autocorrelation consistent covariance matrix estimator. Econometrica, 60(4):953-966.

Bahmani-Oskooee, M. and Nasir, A. (2005). Productivity bias hypothesis and the purchasing power parity: a review article. Journal of Economic Surveys, 19(4):671-696.

Bai, J. and Carrion-i-Silvestre, J. L. (2009). Structural changes, common stochastic trends, and unit roots in panel data. The Review of Economic Studies, 76(2):471-501.

Bai, J. and Ng, S. (2002). Determining the number of factors in approximate factor models. Econometrica, 70(1):191-221.

Bai, J. and Perron, P. (1998). Estimating and testing linear models with multiple structural changes. Econometrica, 66(1):47-78.

Balassa, B. (1964). The purchasing-power parity doctrine: a reappraisal. Journal of Political Economy, 72(6):584-596.

Bénassy-Quéré, A. and Coulibaly, D. (2014). The impact of market regulations on intra-European real exchange rates. Review of World Economics, 150(3):529-556.

Blanchard, O. and Giavazzi, F. (2002). Current account deficits in the euro area: the end of the Feldstein Horioka puzzle? Brookings Papers on Economic Activity, 33(2):147-210.

De Gregorio, J., Giovannini, A., and Wolf, H. C. (1994). International evidence on tradables and nontradables inflation. European Economic Review, 38(6):1225-1244.

Dornbusch, R. (1983). Real interest rates, home goods, and optimal external borrowing. Journal of Political Economy, 91(1):141-153.

Estrada, A., Galí, J., and López-Salido, D. (2013). Patterns of convergence and divergence in the euro area. IMF Economic Review, 61(4):601-630.

Fagan, G. and Gaspar, V. (2007). Adjusting to the euro. Working Paper Series 716, European Central Bank.

Gervais, A. and Jensen, J. B. (2013). The tradability of services: Geographic concentration and trade costs. Working Paper 19759, National Bureau of Economic Research.

Giavazzi, F. and Spaventa, L. (2011). Why the current account may matter in a monetary union: Lessons from the financial crisis in the euro area. In Beblavý, M., Cobham, D., and Ódor, L., editors, The Euro Area and the Financial Crisis, pages 199-221. Cambridge University Press.

Jensen, J. B. and Kletzer, L. G. (2005). Tradable services: Understanding the scope and impact of services outsourcing. Working Paper Series WP05-9, Peterson Institute for International Economics.

Kalantzis, Y. (2015). Financial fragility in small open economies: firm balance sheets and the sectoral structure. The Review of Economic Studies, 82(3):1194-1222.

Kao, C. and Chiang, M. H. (2001). On the estimation and inference of a cointegrated regression in panel data. In Baltagi, B. H., Fomby, T. B., and Hill, R. C., editors, Nonstationary Panels, Panel Cointegration, and Dynamic Panels (Advances in Econometrics, 15), chapter 7, pages 179-222. Emerald Group Publishing Limited. 
Mark, C. N. and Sul, D. (2003). Cointegration vector estimation by panel DOLS and long run money demand. Oxford Bulletin of Economics and Statistics, 65(5):655-680.

Obstfeld, M. and Rogoff, K. S. (1996). Foundations of International Macroeconomics. MIT Press, Cambridge, Massachusetts.

Pesaran, M. H. (2007). A simple panel unit root test in the presence of cross-section dependence. Journal of Applied Econometrics, 22(2):265-312.

Reis, R. (2013). The Portugese slump and crash and the euro crisis. Brookings Papers on Economic Activity, 46(1):143-210.

Samuelson, P. (1964). Theoretical notes on trade problems. Review of Economics and Statistics, 46(2):145154.

Sy, M. (2016). Overborrowing and balance of payments imbalances in a monetary union. Review of International Economics, 24(1):67-98.

van Riet, A. and Roma, M. (2006). Competition, productivity and prices in the euro area services sector. Occasional Paper Series 44, European Central Bank.

Westerlund, J. and Edgerton, D. L. (2008). A simple test for cointegration in dependent panels with structural breaks. Oxford Bulletin of Economics and Statistics, 70(5):665-704. 


\section{Appendix}

Figure A.1 - Share of the non-tradable sector by threshold for the measure of tradability EA11, average over 2000-2013

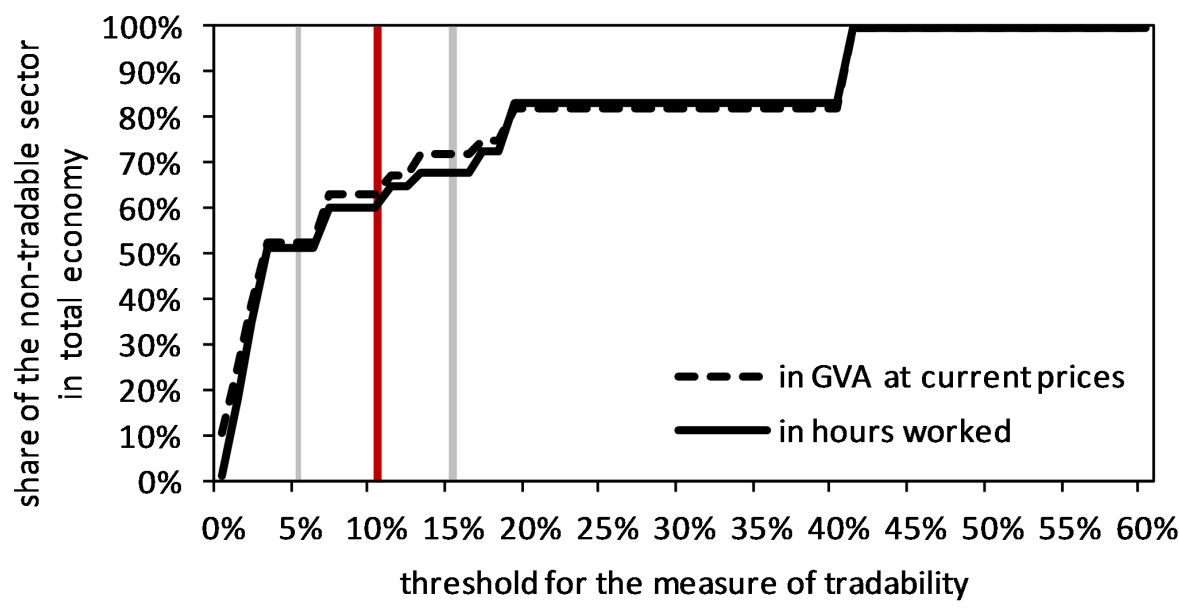

Source: author's calculations using Eurostat, BACI and UN ServiceTrade.

Note: the openness ratio is the ratio of total trade (imports+exports) to total production. The red line indicates the $10 \%$ threshold used here, the grey lines indicate the $5 \%$ and $15 \%$ thresholds used for the robustness tests.

Figure A.2 - Openness ratio by country 2000, 2008 and 2013, in \%

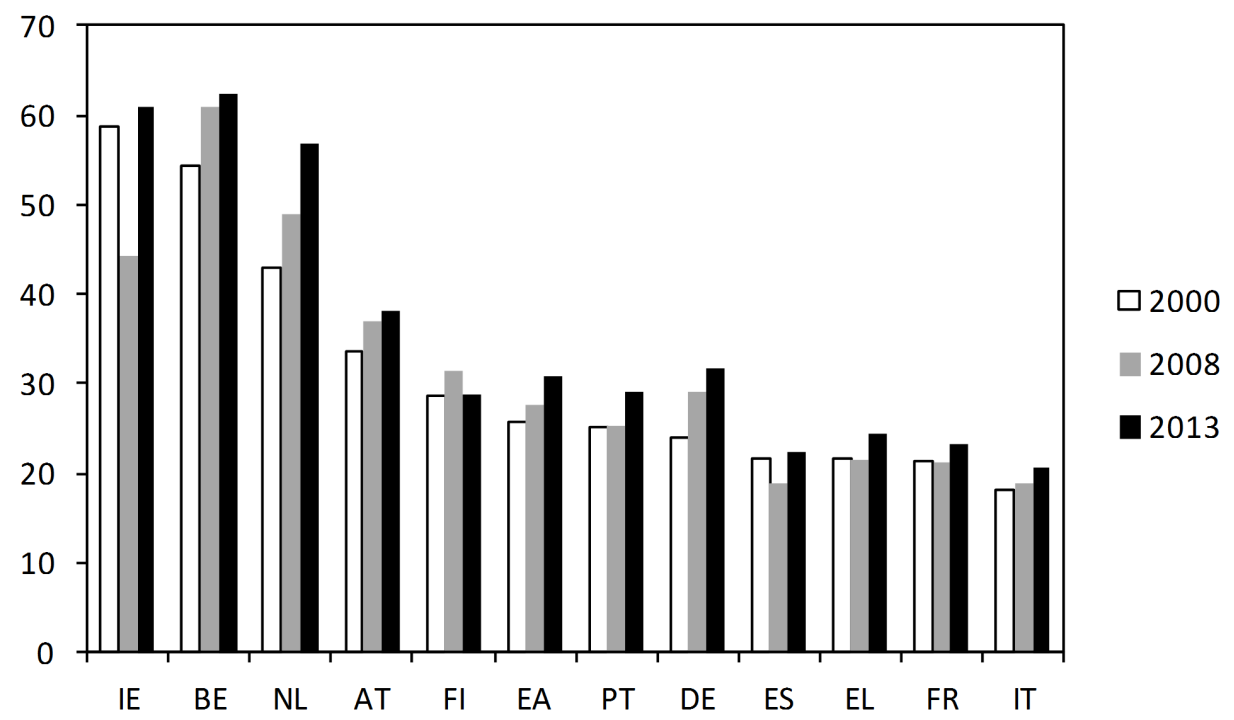

Source: author's calculations using Eurostat, BACI and UN ServiceTrade.

Note: the openness ratio is the ratio of total trade (imports+exports) to total production. 
Table A.1 - Openness ratio by sector, EA11

2000 and 2000-2013 average in \%, 2013/2000 growth in p.p.

\begin{tabular}{|l|l|c|c|c|}
\hline \multicolumn{2}{|l|}{ Sector } & 2000 \\
$(\%)$ & growth (\%) & average (p.p.) \\
$2013-2000$ & $2000-2013$ \\
\hline B & Mining and quarrying & 184.1 & 179.0 & 249.4 \\
\hline C & Manufacturing & 44.0 & 10.1 & 48.4 \\
\hline I & Accommodation and food service activities & 9.4 & 17.4 & 23.7 \\
\hline H & Transportation and storage & 26.1 & -4.1 & 22.8 \\
\hline A & Agriculture, forestry and fishing & 19.0 & 8.2 & 22.8 \\
\hline J & Information and communication & 12.5 & 10.3 & 15.8 \\
\hline N & Administrative and support service activities & 11.0 & 6.3 & 13.7 \\
\hline M & Professional, scientific and technical activities & 9.0 & 3.7 & 9.0 \\
\hline K & Financial and insurance activities & 6.8 & 2.2 & 7.8 \\
\hline G & Wholesale and retail trade; repair of motor vehicles and motorcycles & 3.0 & 0.4 & 3.1 \\
\hline D & Electricity, gas, steam and air conditioning supply & 1.5 & 1.9 & 3.0 \\
\hline F & Construction & 1.9 & 0.0 & 1.7 \\
\hline R & Arts, entertainment and recreation & 2.1 & -0.5 & 1.5 \\
\hline O & Public administration and defence; compulsory social security & 1.9 & -0.8 & 1.4 \\
\hline S & Other service activities & 0.5 & 1.1 & 0.9 \\
\hline P & Education & 0.3 & 0.5 & 0.7 \\
\hline E & Water supply; sewerage, waste management and remediation activities & 0.0 & 0.2 & 0.2 \\
\hline Q & Human health and social work activities & 0.0 & 0.1 & 0.2 \\
\hline L & Real estate activities & 0.0 & 0.0 & 0.0 \\
\hline TOTAL & 33.1 & 6.3 & 34.8 \\
\hline
\end{tabular}

Source: author's calculations using Eurostat, BACI and UN ServiceTrade.

Note: the red lines indicate the 15\%,10\% and 5\% thresholds. The openness ratio is the ratio of total trade (imports+exports) to total production. 
Figure A.3 - Evolution of the non-tradable relative to the tradable sector

$5 \%$ threshold for the measurement of tradability.

(a) $2008 / 1995$

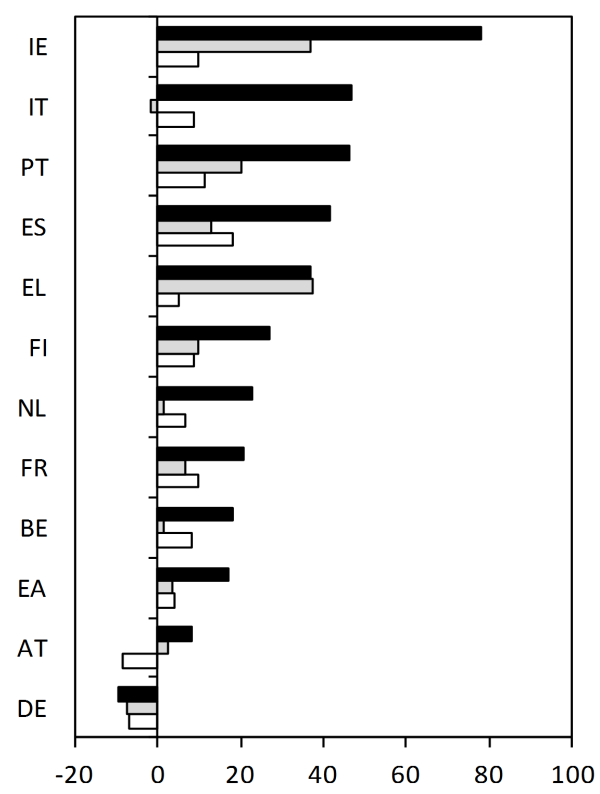

(b) $2013 / 2008$

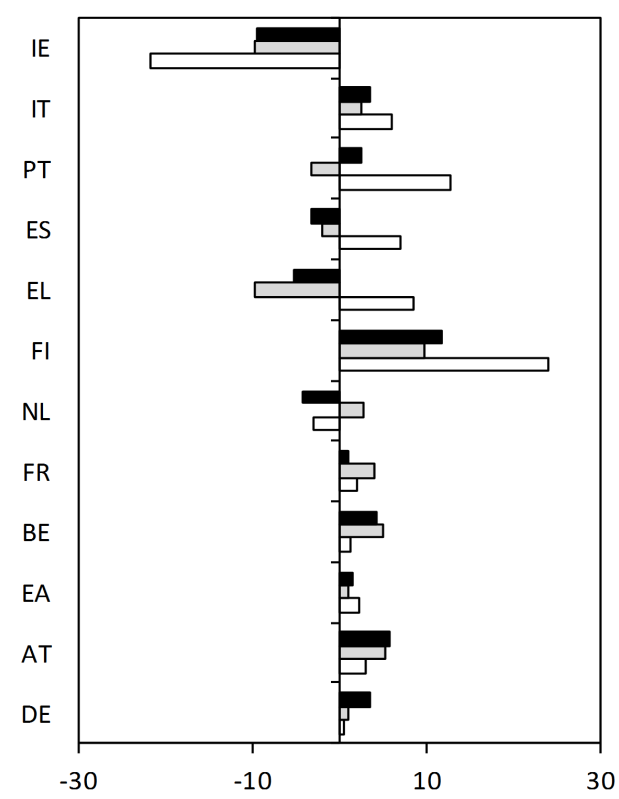

GVA deflator

$\square$ Employment

$\square$ GVA at current prices

$15 \%$ threshold for the measurement of tradability.

(c) $2008 / 1995$

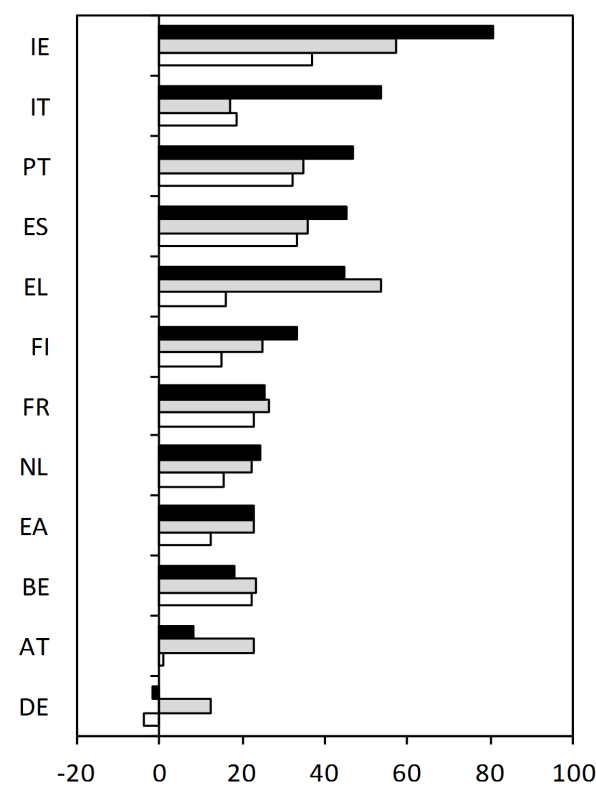

(d) $2013 / 2008$

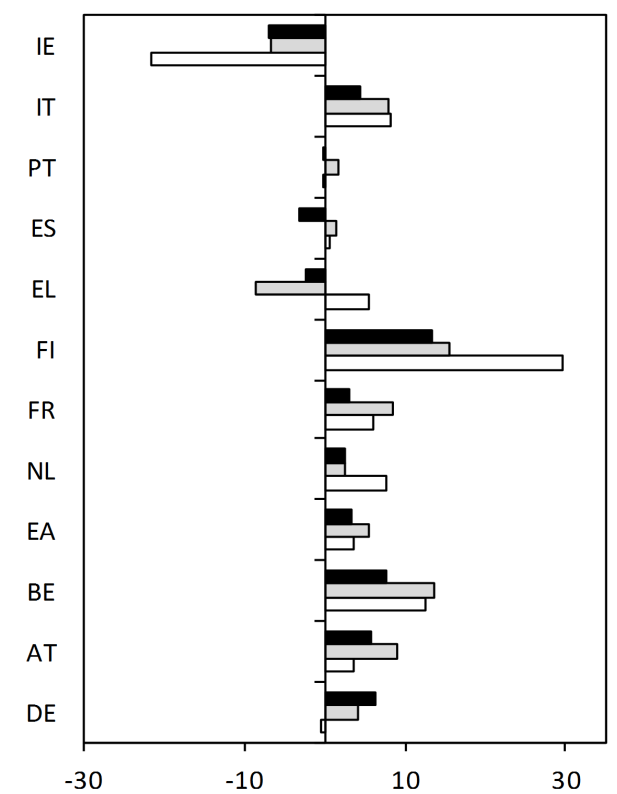

GVA deflator $\square$ Employment $\square$ GVA at current prices

Source: author's calculations using Eurostat, BACI and UN ServiceTrade.

Note: relative prices are the ratio of non-tradable prices relative to the tradable price of the EA 11 . Employment is measured in thousands of hours worked. 
Figure A.4 - Non-tradable prices, productivity in the tradable sector and long-term real interest rate 1995-2013, log deviations from the EA11 average

Austria

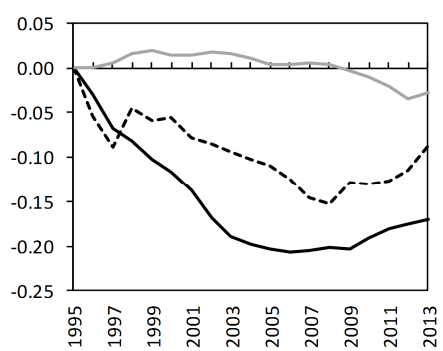

Greece

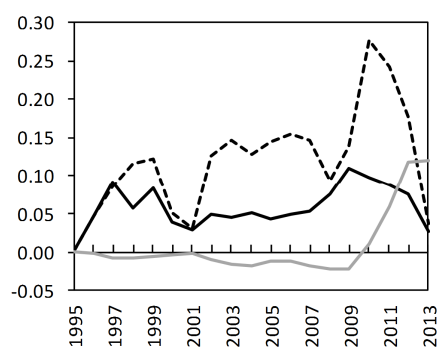

France

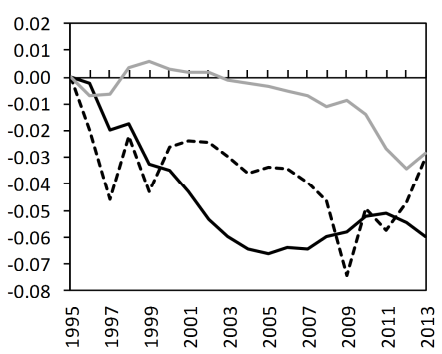

Netherlands

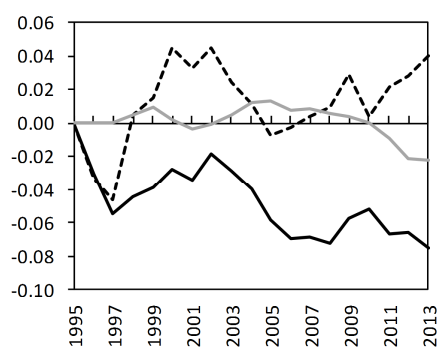

Belgium

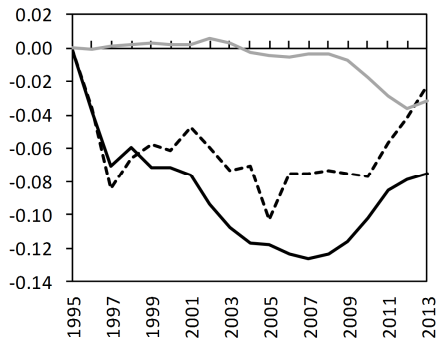

Spain

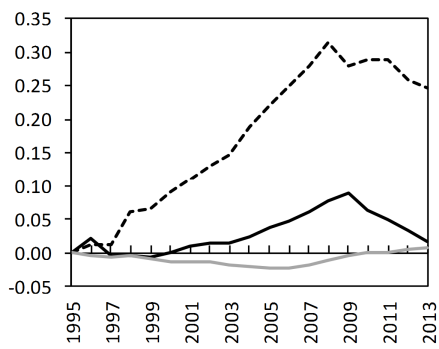

Ireland

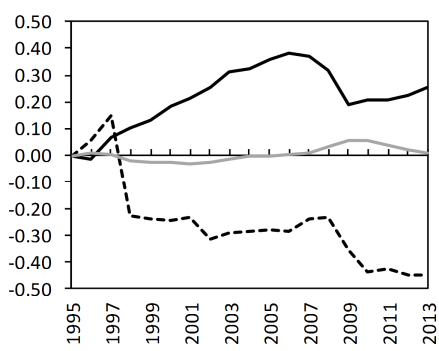

Portugal

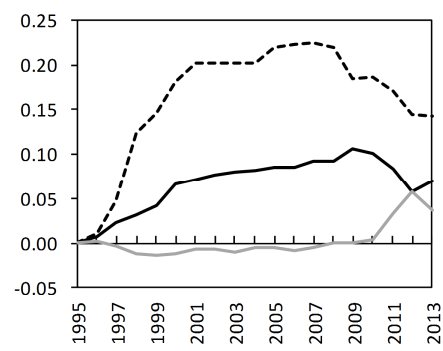

Germany

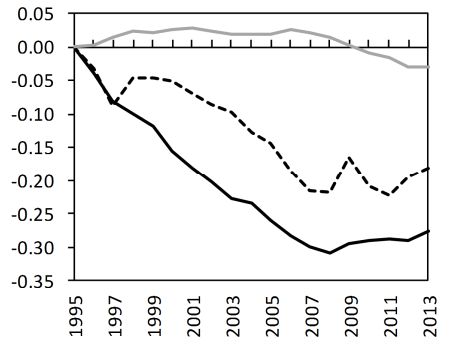

Finland

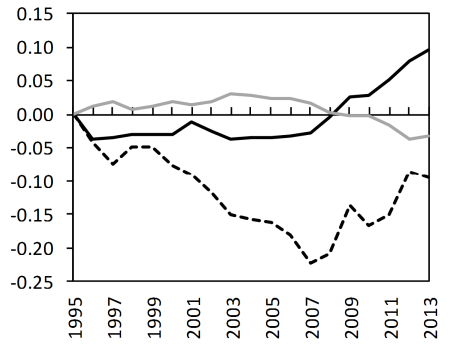

Italy

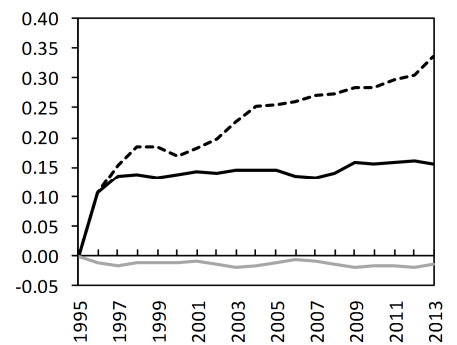

Non-tradable prices

----Productivity in the tradable sector

Real interest rate

Source: author's calculations using Eurostat, BACl and UN ServiceTrade and Ameco.

Note: non-tradable prices and productivity in the tradable sector are measured using the $10 \%$ threshold for tradability. The real interest rate is a 2-year moving average. 
Table A.2 - Third generation panel unit root tests

\begin{tabular}{|c|c|c|c|c|c|c|c|}
\hline & \multicolumn{2}{|c|}{$5 \%$ threshold } & \multicolumn{2}{|c|}{$15 \%$ threshold } & \multicolumn{2}{|c|}{$\begin{array}{l}10 \% \text { threshold } \\
\text { excl. the housing sector }\end{array}$} & \multirow{2}{*}{$\begin{array}{l}10 \% \text { threshold } \\
\ln \left(\frac{C}{C_{E A}}\right)\end{array}$} \\
\hline & $\ln \left(\frac{p_{N}}{p_{N, E A}}\right)$ & $\ln \left(\frac{A_{T}}{A_{T, E A}}\right)$ & $\ln \left(\frac{p_{N}}{p_{N, E A}}\right)$ & $\ln \left(\frac{A_{T}}{A_{T, E A}}\right)$ & $\ln \left(\frac{p_{N}}{p_{N, E A}}\right)$ & $\ln \left(\frac{A_{T}}{A_{T, E A}}\right)$ & \\
\hline \multicolumn{8}{|c|}{ Constant and trend (no break) } \\
\hline$Z$ & -1.463 & -0.008 & -1.191 & -1.177 & -0.951 & -0.689 & -1.499 \\
\hline$P_{m}$ & 2.154 & -0.867 & -0.112 & 0.951 & -0.205 & 0.749 & 0.827 \\
\hline$P$ & 36.285 & 16.251 & 21.257 & 28.310 & 20.643 & 26.967 & 27.484 \\
\hline \multicolumn{8}{|c|}{ Trend shifts } \\
\hline$Z$ & $3.094^{*}$ & 1.349 & 0.587 & 0.458 & $7.817^{*}$ & 0.157 & 0.825 \\
\hline$P_{m}$ & -1.564 & -2.016 & -0.075 & -0.985 & $-2.542 *$ & -0.002 & -0.911 \\
\hline$P$ & 11.628 & 8.63 & 21.504 & 15.465 & 5.135 & 21.989 & 15.959 \\
\hline$Z *$ & $9.523^{*}$ & 1.986 & $4.424^{*}$ & $24.443^{*}$ & 24.444 & 0.996 & 0.995 \\
\hline$P_{m} *$ & -1.758 & -1.817 & -0.538 & -1.478 & $-2.968 *$ & -0.028 & -1.322 \\
\hline$P *$ & 10.336 & 9.951 & 18.432 & 12.596 & 2.309 & 21.845 & 13.231 \\
\hline
\end{tabular}

* the test statistics reject the null hypothesis of a unit root.

Note: Country-specific intercepts and trends are included (model 2). See Bai and Carrion-i-Silvestre (2009) for a description of the tests. The $1 \%, 5 \%$ and $10 \%$ critical values for the absolute value of the standard normal distributed $Z$ and $P_{m}$ statistics are 2.326, 1.645 and 1.282 , while the critical values for the chi-squared distributed $P$ statistic are 40.289, 33.924 and 30.813 , respectively. The number of common factors are estimated using the panel Bayesian information criterion proposed by Bai and $\mathrm{Ng}$ (2002), and the test was estimated with a maximum number of breaks of 3 .

Source: author's calculations. 
Table A.3 - Third generation panel cointegration test of Westerlund and Edgerton (2008)

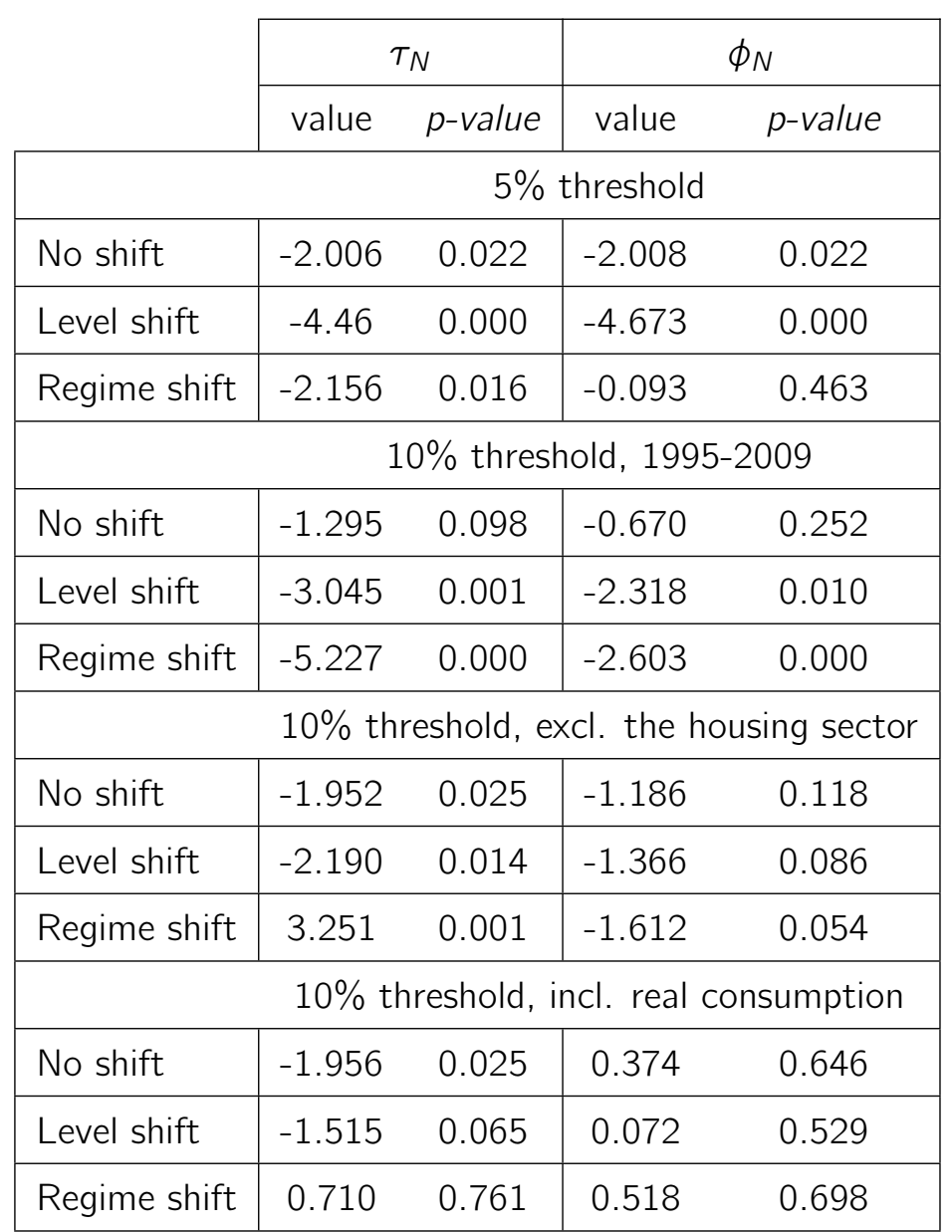

Note: the test has the null hypothesis of no-cointegration. The breaks are determined by grid search at the minimum of the sum of squared residuals. The $p$-values are for one-sided test based on the normal distribution.

Source: author's calculations. 